\title{
PROGRESS REPORT ON THE GROUND-WATER, SURFACE-HATER, AND QUALITY-OF-WATER MONITORING PROGRAM, BLACK MESA AREA, NORTHEASTERN ARIZONA-1987-88
}

By Robert J. Hart and John P. Sottilare

U.S. GEOLOGICAL SURVEY

Open-File Report 88-467

Prepared in cooperation with the ARIZONA DEPARTMENT OF WATER RESOURCES

and the U.S. BUREAU OF INDIAN AFFAIRS 
DEPARTMENT OF THE INTERIOR

DONALD PAUL HODEL, Secretary

U.S . GEOLOGICAL SURVEY

Dallas L. Peck, Director

For additional information write to:

District Chief

U.S. Geological Survey Federal Building, Box FB-44 300 West Congress Street

Tucson, Arizona 85701-1393
Copies of this report can be purchased from:

U.S. Geological Survey Books and Open-File Reports Section Federal Center, Bldg. 810

Box 25425

Denver, Colorado 80225 


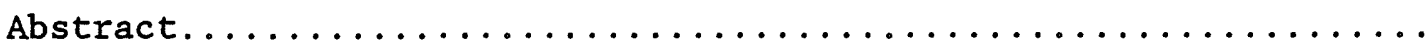

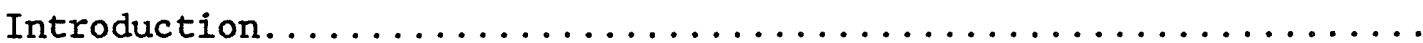

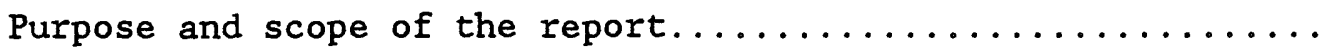

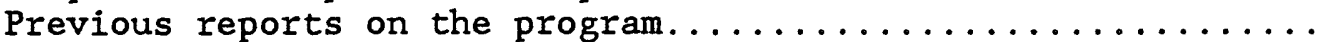

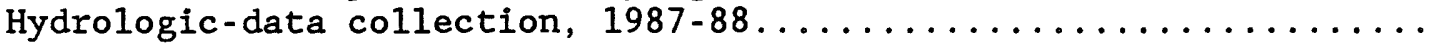

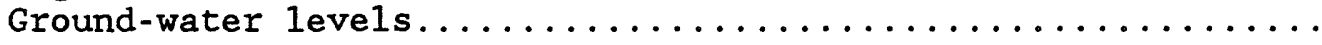

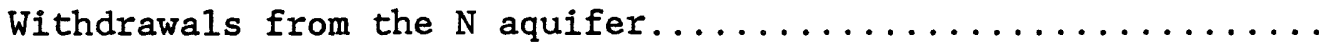

Chemical quality of water from wells that tap

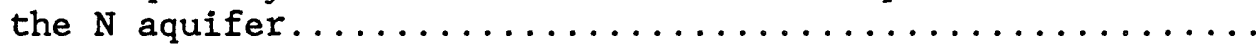

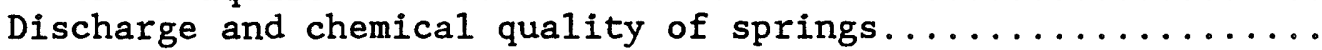

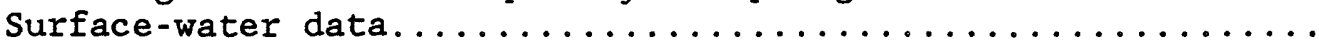

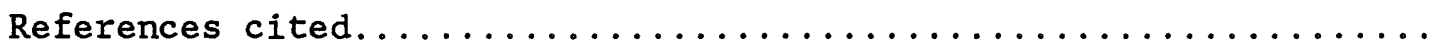

\section{ILLUSTRATIONS}

Figures 1. Maps showing location of study area............. 2

2. Diagram showing rock formations of Black Mesa area....

3. Map showing surface-water and water-quality datacollection sites, 1987-88

4. Map showing water-level changes in wells that tap the $\mathrm{N}$ aquifer, 1953-88. (1) 3

5. Graphs showing measured and simulated water-level changes for observation wells,

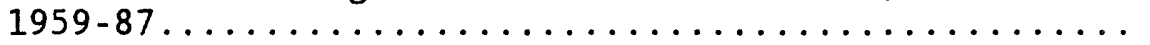

6. Map showing location of well systems monitored for withdrawals from the $N$ aquifer, $1987 \ldots \ldots \ldots \ldots$ 
TABLES

Page

Table 1. Water-level changes in wells that tap the $\mathrm{N}$

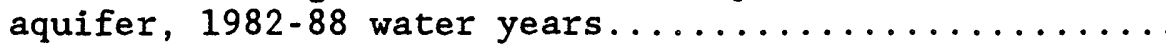

2. Flowmeter test results for industrial and nonindustrial wells that tap the $\mathrm{N}$ aquifer, Black Mesa area, 1988...

3. Withdrawals from the $\mathrm{N}$ aquifer, Black Mesa

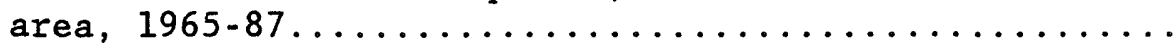

4. Withdrawals from the $\mathrm{N}$ aquifer by well systems,

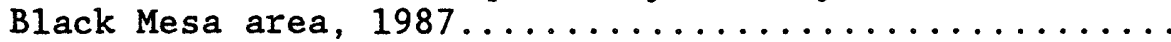

5. Chemical analyses of Peabody Coal Company industrial wells that tap the $\mathrm{N}$ aquifer, Black Mesa area, $1987-88$

6. Selected parameters from chemical analyses of water from Peabody Coal Company wells that tap the $\mathrm{N}$ aquifer, Black Mesa area, 1967-74 and 1980-88.......

7. Chemical analyses of selected springs, Black Mesa area,

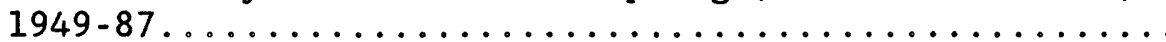

8. Discharge data, Moenkopi Wash at Moenkopi, Black Mesa area, 1986 water year.......................

9. Discharge data, Chinle Creek near Mexican Water, Black Mesa area, 1986 water year................ 
CONVERSION FACTORS

For readers who use metric units, conversion factors for terms used in this report are listed below:

\section{Multiply}

\section{foot ( $f t$ )}

square mile $\left(\mathrm{mi}^{2}\right)$

acre-foot (acre-ft)

cubic foot per second $\left(\mathrm{ft} \mathrm{t}^{3} / \mathrm{s}\right)$

gallon per minute

(gal/min)
$\underline{B y}$

0.3048

2.590

0.001233

0.02832

0.06309

\section{To obtain}

meter (m) square kilometer $\left(\mathrm{km}^{2}\right)$ cubic hectometer $\left(\mathrm{hm}^{3}\right)$ cubic meter per second $\left(\mathrm{m}^{3} / \mathrm{s}\right)$

liter per second $(\mathrm{L} / \mathrm{s})$

Sea leve1: In this report "sea level" refers to the National Geodetic Vertical Datum of 1929 (NGVD of 1929)-A geodetic datum derived from a general adjustment of the first-order level nets of both the United States and Canada, formerly called Sea Level Datum of 1929. 
PROGRESS REPORT ON THE GROUND-WATER, SURFACE-WATER, AND

QUALITY-OF-WATER MONITORING PROGRAM, BLACK MESA AREA, NORTHEASTERN ARIZONA-1987-88

By

Robert J. Hart and John P. Sottilare

ABSTRACT

The Black Mesa monitoring program is designed to determine longterm effects on the water resources of the area resulting from withdrawals of ground water from the $N$ aquifer by the strip-mining operation of Peabody Coal Company. Withdrawals by Peabody Coal Company increased from 95 acrefeet in 1968 to 3,832 acre-feet in 1987. The $\mathrm{N}$ aquifer is an important source of water in the 5,400-square-mile Black Mesa area on the Navajo and Hopi Indian Reservations.

Water levels in the confined area of the aquifer declined as much as 95.1 feet near Keams Canyon from 1965 to 1988. Part of the decline in the measured municipal wells may be due to local pumping. During 1965-88, water levels in wells that tap the unconfined area of the aquifer have not declined significantly and have risen in many areas. Chemical analyses indicate no significant changes in the quality of water from wells that tap the $N$ aquifer or from springs that discharge from several stratigraphic units, including the $\mathrm{N}$ aquifer, since pumping began at the mine.

\section{INTRODUCTION}

The $N$ aquifer is an important source of water in the 5,400square-mile Black Mesa area on the Navajo and Hopi Indian Reservations in northeastern Arizona ( $f i g .1$ ). The aquifer consists of three rock formations that have been historically referred to as the $N$ aquifer. The major water-bearing rock formations are the Navajo Sandstone of Jurassic and Triassic(?) age and Lukachukai Member of the Wingate Sandstone of Triassic age. The Kayenta Formation underlies the Navajo Sandstone and yields small amounts of water (fig. 2).

On the northern part of the mesa, Peabody Coal Company operates a strip mine in a lease area of about 100 square miles. When operation of the mine began in 1968, the company pumped about 95 acre-feet of ground water from the $\mathrm{N}$ aquifer; in $1987,3,832$ acre-feet was pumped. Withdrawals from the $N$ aquifer for municipal use increased from an estimated 70 acrefeet in 1965 to about 2,400 acre-feet in 1987. The Navajo and Hopi Tribes became concerned about the long-term effects of withdrawals from the $N$ aquifer on supplies for domestic and municipal purposes. These and other concerns about the effects of strip mining led to the water-resources investigation of the Black Mesa area by the U.S. Geological Survey in cooperation with the Arizona Department of Water Resources in 1971 . In 1983, the U.S. Bureau of Indian Affairs joined the cooperative effort. 


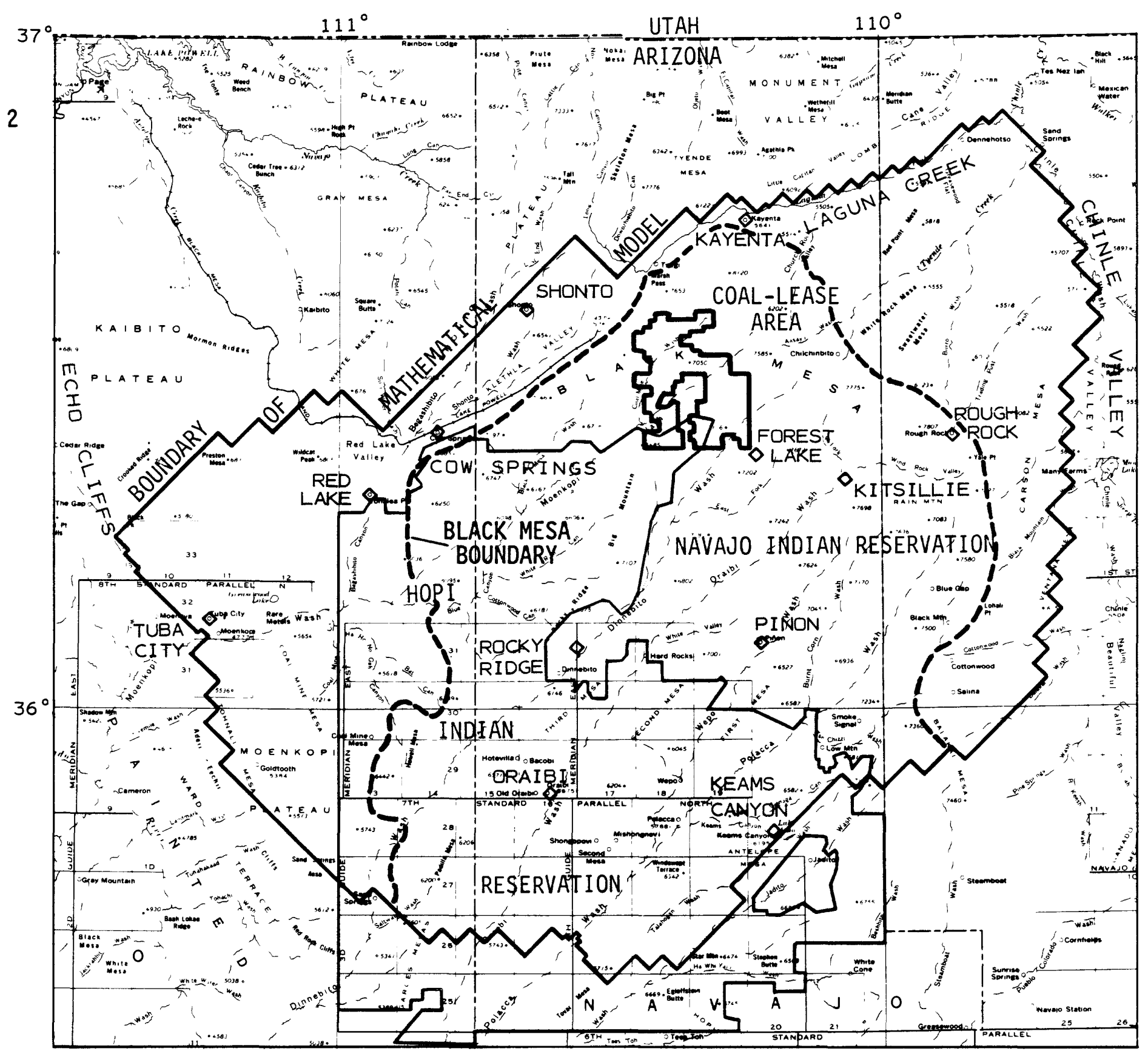

BASE FROM U.S. GEOLOGICAL SURVEY

STATE BASE MAP, 1:1,000,000

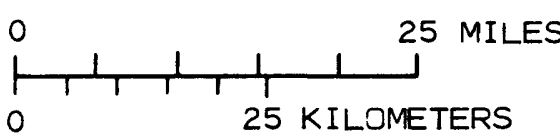

Figure 1.--Location of study area.

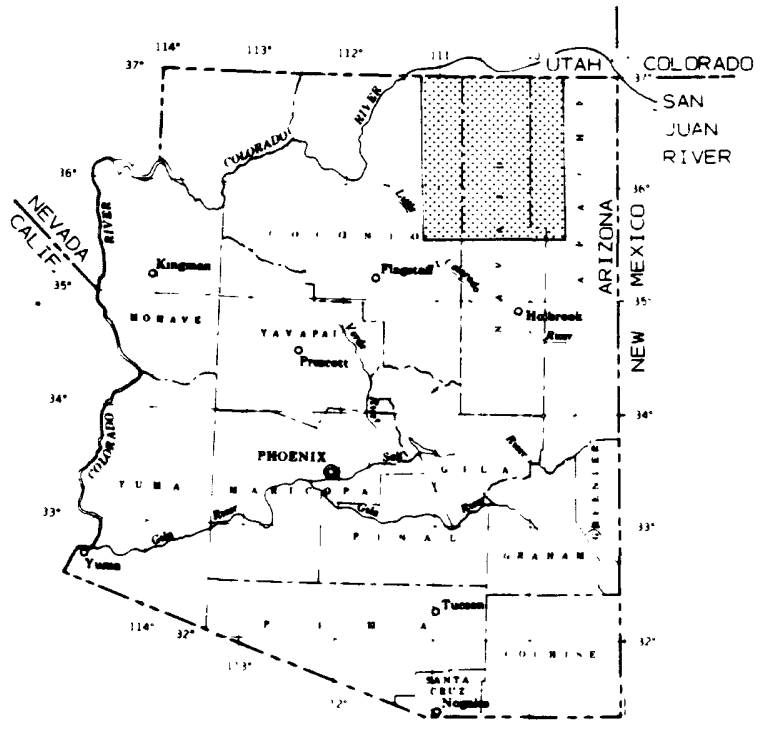




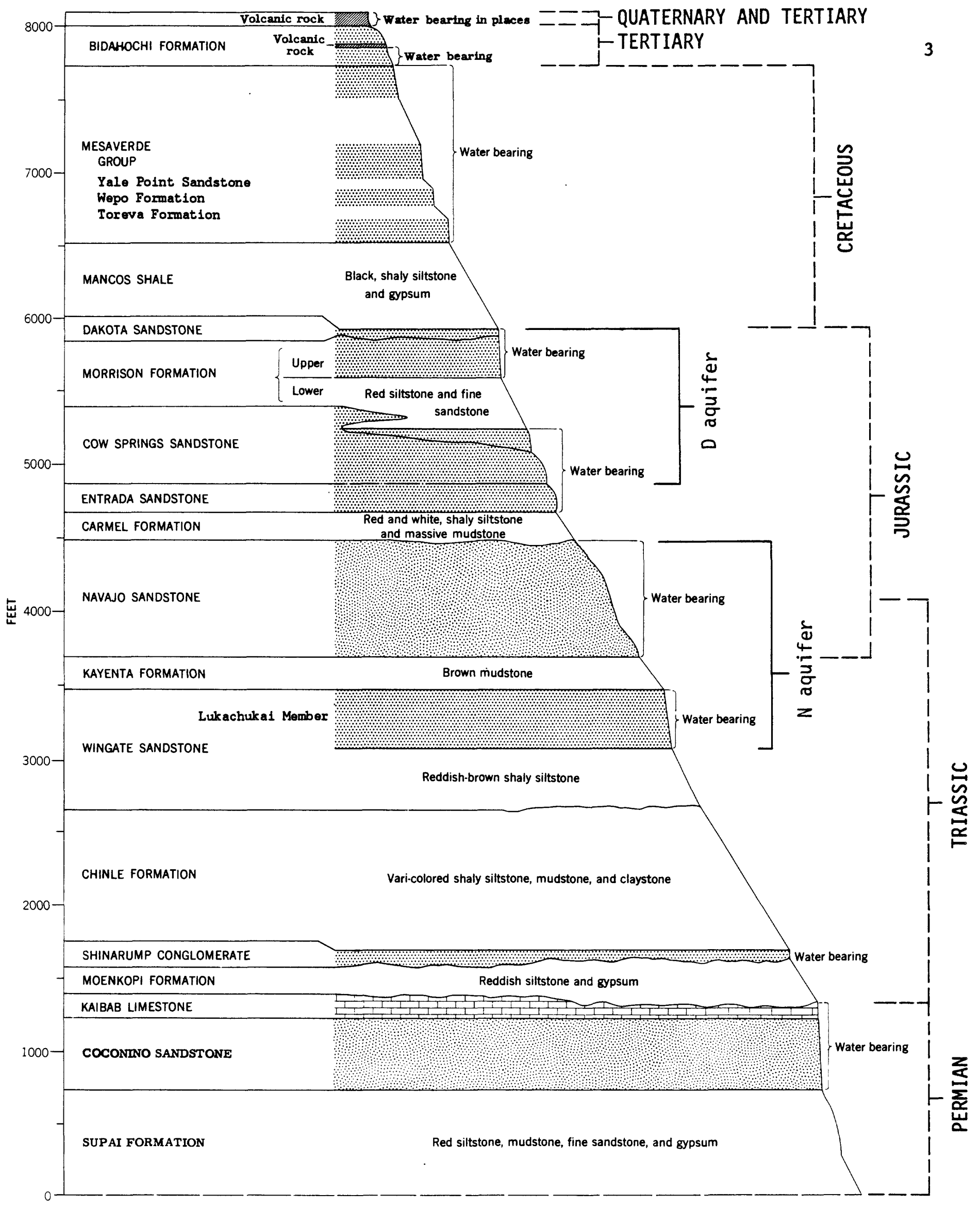

Figure 2.--Rock formations of the Black Mesa area. 
The cooperation and assistance of the Navajo and Hopi Tribes and Peabody Coal Company are gratefully acknowledged. The Navajo Tribal Utility Authority; Peabody Coal Company; the Hopi Tribe, and the Western Navajo Agency, Chinle Agency, and Hopi Agency of the U.S. Bureau of Indian Affairs assisted in the collection of pumpage data and testing of flowmeters. The Hopi Tribe, the Navajo Tribal Utility Authority, and the U.S. Bureau of Indian Affairs assisted in the collection of water-level data.

\section{Purpose and Scope of the Report}

This report covers the progress of the ground-water, surfacewater, and quality-of-water monitoring program, Black Mesa area, northeastern Arizona, from July 1, 1987, to June 30, 1988. Except for some earlier data that are used for comparison, only new data will appear in this report. The scope of the work included water-level measurements, chemical analyses of ground water and spring water, compilation of pumpage data, accuracy tests of flowmeters, and measurement of spring and surfacewater discharge. These data were collected to determine the effects of industrial and nonindustrial pumpage from the $N$ aquifer.

\section{Previous Reports on the Program}

Six progress reports have been prepared by the U.S. Geological Survey on the monitoring phase of the program (U.S. Geological Survey, 1978; G.W. Hill, hydrologist, U.S. Geological Survey, written commun., 1982, 1983; Hill, 1985; Hill and Whetten, 1986; Hill and Sottilare, 1987). Most of the data obtained from the monitoring program is contained in these reports except for stream-discharge and sediment-discharge data from Moenkopi Wash collected prior to the 1986 water year, which were published in Water Resources Data for Arizona (U.S. Geological Survey, 1976-88). Eychaner (1983) showed the results of a mathematical model that was developed to simulate the flow of ground water in the $\mathrm{N}$ aquifer. The model was used to predict the effects of withdrawals through the year 2014 . The model was converted to a new model program and recalibrated by using revised estimates of selected aquifer parameters and a finer spatial grid (Brown and Eychaner, 1988). The new model was used to predict effects of five pumping scenarios through the year 2051. The monitoring program is essential for checking the model simulations and determining water quality of the $\mathrm{N}$ aquifer as water levels decline.

HYDROLOGIC-DATA COLLECTION, 1987-88

Monitoring activities include continuous or periodic measurements of (1) ground-water levels in the confined and unconfined areas of the $N$ aquifer; (2) major withdrawals from the confined and unconfined areas; (3) ground-water quality of the $N$ aquifer in the coal-lease area; (4) discharge and chemical quality of selected springs that flow from the various formations, including the $N$ aquifer; and (5) surface-water discharge. The surface-water and water-quality data-collection sites are shown in figure 3 . 
Ground-Water Leve1s

Ground-water levels in nonindustrial wells in the confined area of the $N$ aquifer have continued to decline since 1968 when Peabody Coal Company began withdrawals from wells in the area. Water-level data collected from December 1987 to May 1988, however, showed that water levels in several nonindustrial wells in the confined area of the $N$ aquifer had risen or had not changed since last measured during water year 1987 . These wells are 8T-500 (BM3), Chilchinbito PM3, 8K-443, 10R-111, and 10T-258, and Keams Canyon 2 ( $f i g .4$, table 1). Water levels in Keams Canyon 2 increased 18.9 feet since previously measured in water year 1987 . Water levels in observation well BM6, about 15 miles south of the mine well field, had declined about 2.7 feet since previously measured in water year 1987. Most of the observation and nonindustrial wells in the northeastern section of the confined area of the $\mathrm{N}$ aquifer showed record declines.

Part of the decline in municipal wells probably is caused by local pumping. Pumping from the Kayenta municipal well field also may affect water levels in observation well 8T-500 (BM3). Withdrawals are not made from any observation wells.

Significant water-level changes have not occurred in wells in the unconfined area of the $\mathbf{N}$ aquifer since pumping began at the mine. However, well 3T-333 at Tuba City had a decline of 9 feet, which probably is the result of local pumping (fig. 4, table 1).

Eychaner (1983) developed a mathematical model of the $\mathrm{N}$-aquifer system on the basis of available information about the aquifer. Waterlevel changes were simulated for several nonindustrial wells and continuous-record observation wells that penetrate the $\mathrm{N}$ aquifer. During 1985, the model was rerun with measured withdrawals for 1980-84 to check the continued agreement of measured and simulated water levels. Results of these model runs are given in the 1987 progress report (Hill and Sottilare, 1987). Brown and Eychaner (1988) recalibrated the 1983 model using a finer grid that provided more detail near Kayenta, Tuba City, Keams Canyon, Oraibi, and the coal-lease area.

Simulated water-level changes for 1965-84 using the 1988 model generally agree with water-level changes measured in all six continuousrecord observation wells (fig. 5) and are nearly identical to water-level changes simulated by the 1983 model. In both models, the greatest inconsistency between measured and simulated water levels occurred at well $8 \mathrm{~T}-500$ (BM3). Changes in the location and the amount of pumpage for Kayenta have influenced the water levels in well BM3. The parallel trends of the observed and simulated water levels however indicate that the 1988 model is a reasonable representation of the actual ground-water conditions in the study area.

\section{Withdrawals from the $N$ Aquifer}

The three categories of ground-water withdrawal from the $N$ aquifer are industrial (Peabody Coal Company) from the confined area, nonindustrial from the confined area, and nonindustrial from the unconfined 


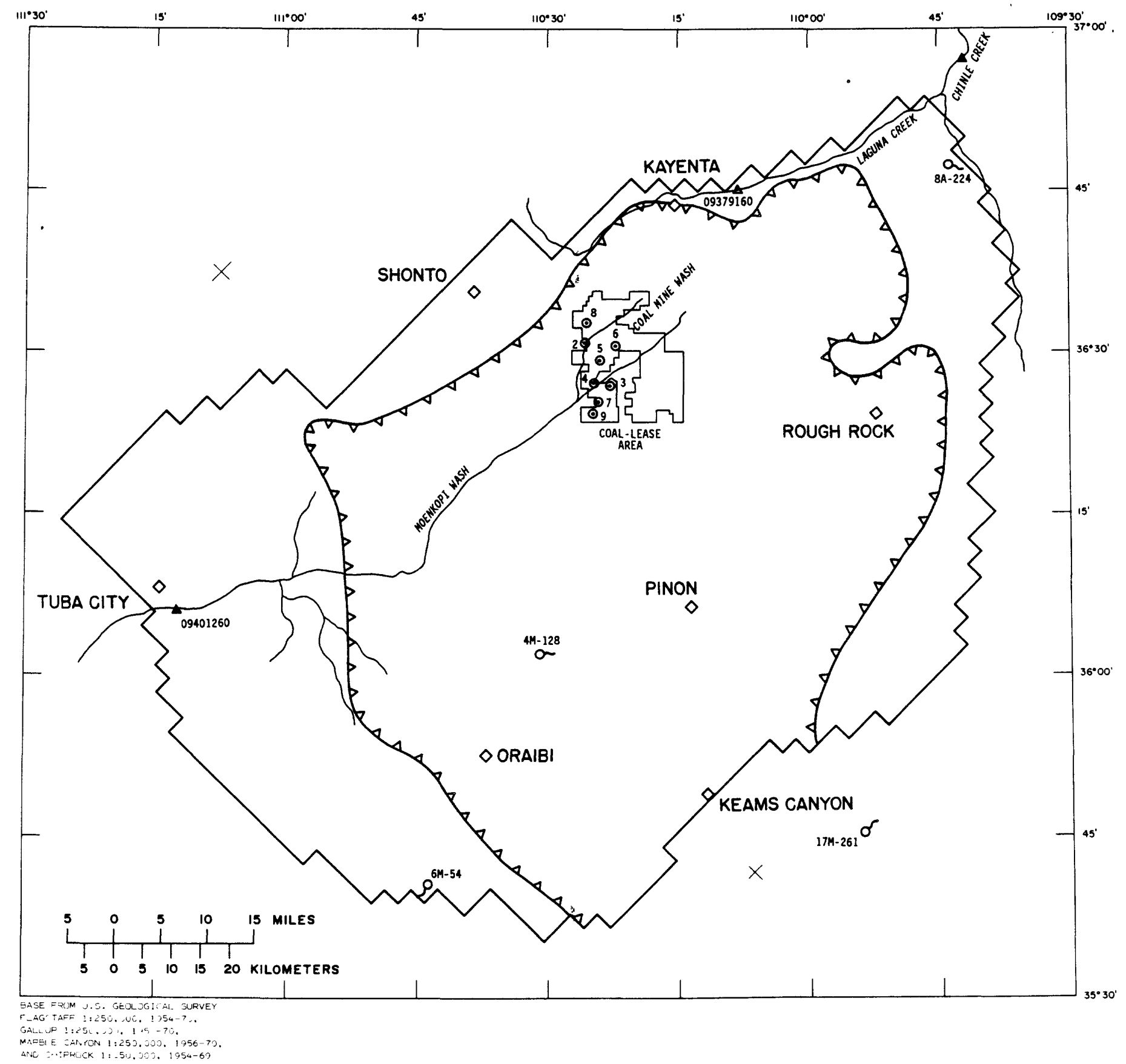

Figure 3.--Surface-water and water-quality data-collection sites, 1987-88. 
$O_{9}$

WELL OWNED BY PEABODY COAL COMPANY IN WHICH WATERQUALITY SAMPLE WAS COLLECTED-9, is well number

a

$6 \mathrm{M}-54$

SPRING AT WHICH DISCHARGE WAS MEASURED AND WATER-QUALITY SAMPLE WAS COLLECTED-6M-54, is spring identification number

09401260

STREAMFLOW-GAGING STATION OPERATED BY THE U.S. GEOLOGICAL SURVEY AT WHICH SURFACE-WATER DATA WERE COLLECTED-09401260, is station number

$\triangle$

09379160

LOW-FLOW MEASUREMENT SITE-09379160, is siteidentification number

CONFINED

$\frac{\triangle \triangle \wedge \wedge \wedge \wedge \sim \wedge}{\text { UNCONFINED }}$

APPROXIMATE BOUNDARY BETWEEN CONFINED AND UNCONFINED CONDITIONS-From Eychaner (1983)

BOUNDARY OF MATHEMATICAL MODEL-From Eychaner (1983) 


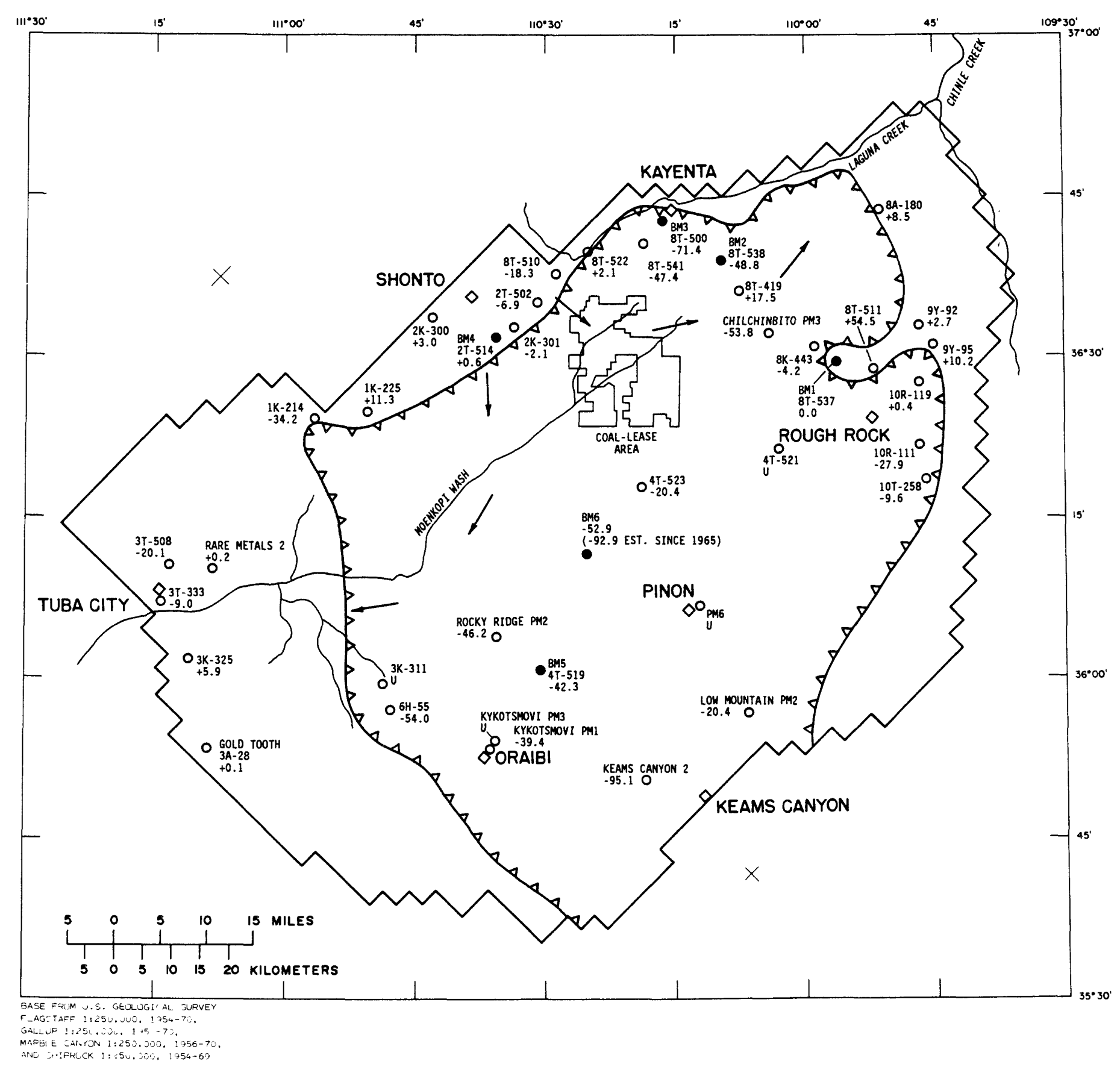

Figure 4.--Water-level changes in wells that tap the $\mathrm{N}$ aquifer, 1953-88. 
0

$4 \mathrm{~T}-523$

$-20.4$

$8 \mathrm{~T}-500$

BM3
WELL IN WHICH DEPTH TO WATER WAS MEASURED

ANNUALLY-First entry, 4T-523, is Bureau of Indian Affairs identification number; second entry, -20.4 , is change in water level, in feet, between measurements made during the prestress period and measurements made during 1987-88.

$U$, unable to measure

CONTINUOUS WATER-LEVEL RECORDING SITE (OBSERVATION WELL) MAINTAINED BY THE U.S. GEOLOGICAL SURVEY-First entry, $8 \mathrm{~T}-500$, is Bureau of Indian Affairs identification number; second entry, (BM3), is U.S. Geological Survey identification number

CONFINED

$\triangle \triangle \triangle \triangle \triangle \triangle \triangle \triangle$ UNCONFINED
GENERALIZED DIRECTION OF GROUND-WATER FLOW

BOUNDARY OF MATHEMATICAL MODEL-From Eychaner (1983) 


\begin{tabular}{|c|c|c|c|c|c|c|c|c|c|}
\hline \multirow{2}{*}{ Location } & \multirow{2}{*}{$\begin{array}{l}\text { U.S. } \\
\text { Bureau } \\
\text { of } \\
\text { Indian } \\
\text { Affairs } \\
\text { field } \\
\text { number }\end{array}$} & \multirow{2}{*}{$\begin{array}{c}\text { Pre- } \\
\text { stress } \\
\text { water } \\
\text { level, in } \\
\text { feet below } \\
\text { land } \\
\text { surface }\end{array}$} & \multicolumn{7}{|c|}{ Water-level change, in feet below land surface } \\
\hline & & & $\begin{array}{r}1982 \\
\text { water } \\
\text { year }\end{array}$ & $\begin{array}{r}1983 \\
\text { water } \\
\text { year }\end{array}$ & $\begin{array}{r}1984 \\
\text { water } \\
\text { year }\end{array}$ & $\begin{array}{r}1985 \\
\text { water } \\
\text { year }\end{array}$ & $\begin{array}{r}1986 \\
\text { water } \\
\text { year }\end{array}$ & $\begin{array}{r}1987 \\
\text { water } \\
\text { year }\end{array}$ & $\begin{array}{r}1988 \\
\text { water } \\
\text { year }\end{array}$ \\
\hline Tuba City & $3 T-333$ & 23.0 & -5.0 & -5.1 & -11.7 & -13.7 & -10.5 & -11.8 & -9.0 \\
\hline Do. & $3 K-325$ & 208 & +4.3 & +3.9 & +4.6 & +4.2 & +15.2 & +4.7 & +5.9 \\
\hline Gold Tooth & $3 A-28$ & 230 & ---- & -1.4 & 0.0 & -8.6 & +9.2 & -3.3 & +0.1 \\
\hline Rocky Ridge & PM2 & 432 & -30.4 & -34.4 & ----- & -39.8 & -41.1 & -44.1 & -46.2 \\
\hline Kykot smovi & PM1 & ${ }^{1} 220$ & ---- & -31.0 & -38.7 & -30.2 & ---- & -37.9 & -39.4 \\
\hline Do. & PM3 & 2210 & -12.2 & ---- & ---- & ---- & -11.9 & $(9)$ & $(9)$ \\
\hline Keams Canyon & 2 & 292.5 & -75.7 & -84.9 & --- & --- & -81.4 & -114 & -95.1 \\
\hline Low Mountain & PM2 & 551 & ---- & -8.9 & -12.2 & -14.9 & $10^{-17.4}$ & -19.4 & -20.4 \\
\hline Pinon & PM6 & 3743.6 & ---- & $\left({ }^{9}\right)$ & --- & --.-- & $10-39.7$ & $\left({ }^{9}\right)$ & $\left({ }^{9}\right)$ \\
\hline Forest Lake & $4 T-523$ & $1,096.0$ & ---- & +1.6 & ---- & ---- & -17.2 & -19.6 & -20.4 \\
\hline Kitsillie & $4 T-521$ & $5_{1,254}$ & ---- & ---- & --- & -.-- & -69.6 & $(9)$ & $(9)$ \\
\hline White Mesa Arch & $1 K-214$ & 188 & -34.2 & -33.8 & -33.6 & -33.6 & -22.2 & -33.3 & -34.2 \\
\hline Cow Spring & $1 K-225$ & 60 & +8.1 & +8.0 & +8.9 & +9.7 & +13.2 & +10.6 & +11.3 \\
\hline Shonto & $2 K-300$ & 176.5 & +2.8 & +2.7 & +3.2 & +3.5 & +4.3 & +3.5 & +3.0 \\
\hline Chilchinbito & PM3 & 405 & -38.9 & -50.3 & -64.3 & -73.2 & -46.7 & -55.4 & -53.8 \\
\hline Rough Rock & $8 T-511$ & 505 & +53.6 & $\left({ }^{9}\right)$ & +50.3 & +49.8 & +53.2 & +53.8 & +54.5 \\
\hline Do. & $10 R-111$ & 170.0 & -28.2 & -28.7 & -41.4 & -29.8 & -18.7 & -31.0 & -27.9 \\
\hline Do. & $10 T-258$ & 301.0 & -6.1 & -12.2 & -8.5 & -13.8 & +2.8 & -16.3 & -9.6 \\
\hline Do. & $10 R-119$ & 256.6 & +0.2 & -0.2 & +1.5 & -0.9 & +0.6 & +1.3 & +0.4 \\
\hline Do. & $9 Y-95$ & 119.5 & +4.2 & +8.9 & +9.8 & +10.5 & +14.7 & +6.6 & +10.2 \\
\hline Do. & $9 Y-92$ & 168.8 & +1.5 & +1.1 & -1.4 & +0.9 & +9.5 & +1.1 & +2.7 \\
\hline Northeast Rough Rock & $8 A-180$ & 46.9 & +2.2 & +2.3 & +2.7 & +3.0 & +4.3 & +3.1 & +8.5 \\
\hline BM5 & $4 T-519$ & 323.8 & --- & -28.3 & -30.5 & -33.6 & -35.8 & -39.5 & -42.3 \\
\hline BM6 & BM6 & 735.6 & -26.0 & -29.1 & -36.1 & -43.1 & -46.9 & -50.2 & -52.9 \\
\hline Do. & & ${ }^{8} 695.6$ & -66.0 & -69.1 & -76.1 & -83.1 & -86.9 & -90.2 & -92.9 \\
\hline Shonto Southeast & $2 \mathrm{~K}-301$ & 283.9 & -0.8 & -1.3 & -1.8 & $-\cdots$ & -2.3 & -1.6 & -2.1 \\
\hline BM4 & $2 T-514$ & 217 & +0.6 & +0.2 & +0.3 & +0.6 & +0.7 & +0.7 & +0.6 \\
\hline Sweetwater Mesa & $8 K-443$ & 529.4 & $\left(\begin{array}{l}9 \\
0\end{array}\right)$ & -2.7 & -3.2 & -4.1 & -4.0 & -4.2 & -4.2 \\
\hline BM1 & $8 \mathrm{~T}-537$ & 374.0 & $(9)$ & $\left({ }^{9}\right)$ & -0.9 & +0.2 & -0.9 & +0.1 & 0.0 \\
\hline Long House Valley & $8 T-510$ & 199 & -18.2 & -19.0 & -8.3 & -21.8 & -16.8 & -16.9 & -18.3 \\
\hline Shonto Southeast & $2 T-502$ & $1_{405.8}$ & -14.1 & -9.3 & -9.1 & -12.9 & -8.8 & -8.7 & -6.9 \\
\hline BM2 & $8 T-538$ & 125.0 & -27.0 & -31.2 & -35.7 & -39.0 & -43.5 & -46.8 & -48.8 \\
\hline Owl Spring & $8 T-419$ & 438 & +8.5 & +8.3 & +6.5 & +16.0 & +15.1 & +17.5 & +17.5 \\
\hline Marsh Pass & $8 T-522$ & 125.5 & +3.1 & +2.9 & +3.7 & +4.5 & +3.5 & +2.4 & +2.1 \\
\hline BM3 & $8 T-500$ & 60.0 & -57.5 & -59.5 & -62.1 & -69.5 & -60.5 & -76.0 & -71.4 \\
\hline Kayenta West & $8 T-541$ & $5_{227}$ & ----- & -12.5 & -14.6 & -22.6 & -23.2 & -34.8 & -47.4 \\
\hline Howell Mesa & $3 K-311$ & 463 & $(9)$ & +11.1 & -4.2 & +10.6 & +13.7 & $(9)$ & $(9)$ \\
\hline Do. & $6 \mathrm{H}-55$ & 212 & -55.8 & -53.1 & -54.0 & -53.0 & -53.4 & -53.8 & -54.0 \\
\hline Tuba City & Rare Met. 2 & 57 & -4.1 & -1.5 & -1.4 & -0.5 & -0.5 & -0.1 & +0.2 \\
\hline Tuba NTUA 1 & $3 T-508$ & 629.0 & -21.1 & -20.5 & -17.4 & -22.9 & -29.8 & ----- & -20.1 \\
\hline
\end{tabular}

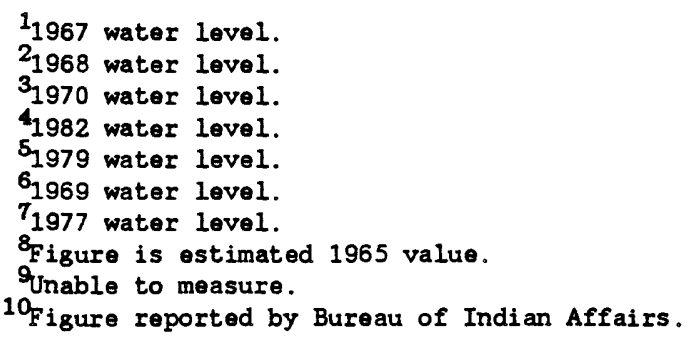



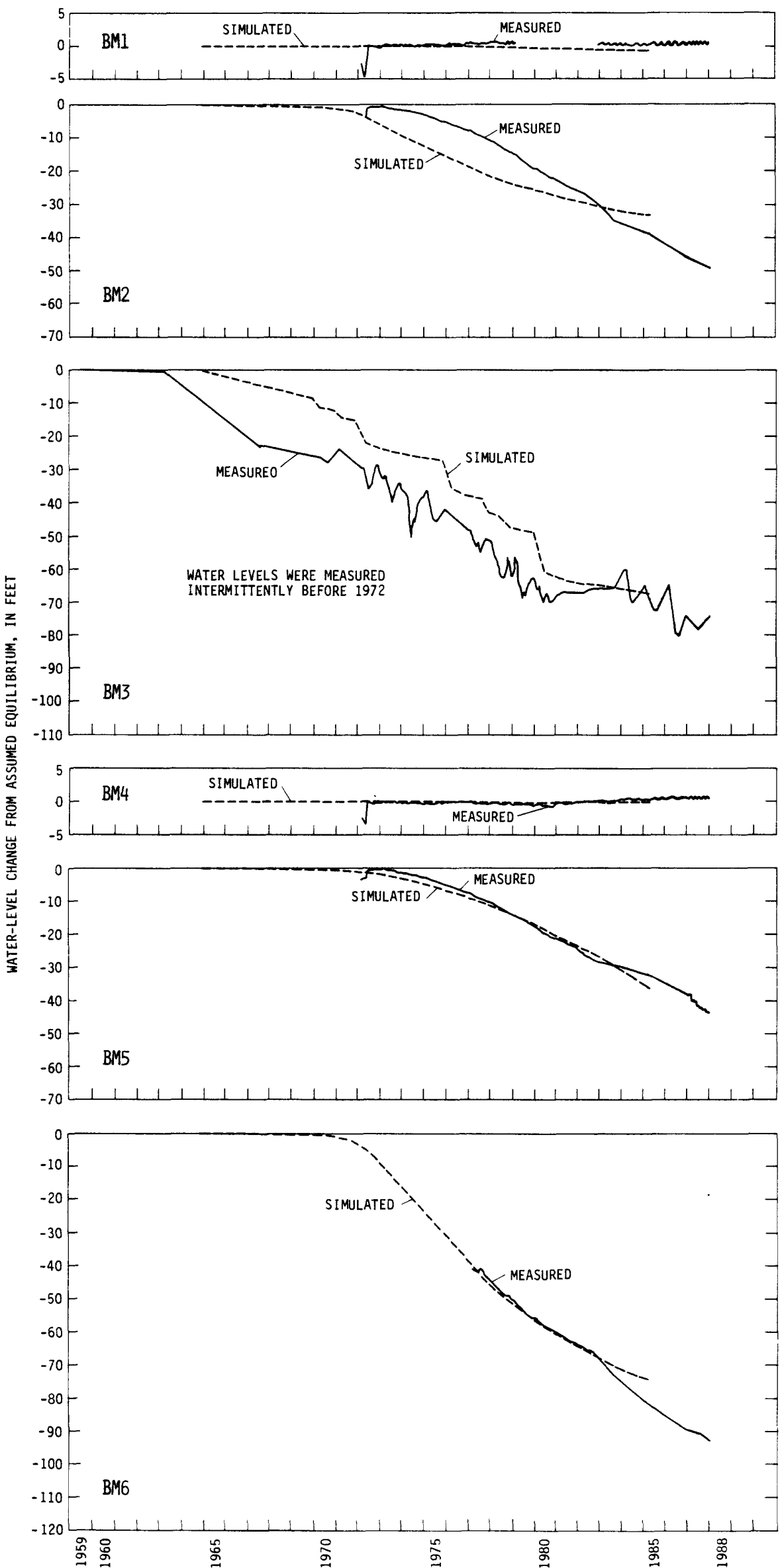

Figure 5.--Measured and simulated water-level changes for observation wells, 1959. 
area. The primary interest is in withdrawals related to the mining operation and nonindustrial withdrawals of significant amounts. Pumpage data have not been collected from wells equipped with windmills.

The U.S. Geological Survey has continued its efforts to improve and ensure accuracy of withdrawal data from industrial and nonindustrial we1ls that penetrate the $N$ aquifer in the study area. The U.S. Bureau of Indian Affairs, Navajo Tribal Utility Authority, and Hopi Tribe operate nonindustrial we 11 systems that consist of about 70 we1ls. These we11 systems serve the Navajo and Hopi Tribes in the Black Mesa area. The industrial system, which includes eight wells - the Peabody Coal Company mine well field withdraws water from the $N$ aquifer within the study area. During 1988, the Geological Survey made an inventory of the wells and tested the accuracy of the flowmeters. This quality-assurance program was initiated during 1985-86 and is conducted every third year on all wells that penetrate the $N$ aquifer except those with windmills.

Two methods were used to test the accuracy of flowmeters. Most meters were tested using a volumetric method. With this method, the volume of water pumped through the flowmeter was measured volumetrically over a period of time and compared with the flowmeter reading for the same period. Owing to the high discharge rates for a few wells, the flow rates were measured using a Cox flowmeter. Results were compared to the flowmeter readings. The results are shown as a percent difference of the metered pumpage from the measured pumpage (table 2). The following equation was used:

\section{Metered pumpage - measured pumpage $\times 100=$ percent difference. \\ Measured pumpage}

For the purpose of this study, the allowable limit between metered and measured pumpage should be no greater than \pm 10 percent.

Annual pumpage for the three categories of withdrawals from the $\mathrm{N}$ aquifer for 1965-87 is given in table 3. Withdrawals during the 1987 calendar year from nonindustrial and industrial well systems that pump from the $\mathrm{N}$ aquifer are given in table 4. Locations of these well systems are shown in figure 6 .

\section{Chemical Quality of Water from We1ls that Tap the $N$ Aquifer}

A major concern on the part of some residents of the Black Mesa area has been the effect of withdrawals on the chemical quality of water in the $N$ aquifer. Eychaner (1983) stated that some water may enter the $N$ aquifer from the upper confining beds. He also stated that the driving force for such flow is present because the head in the overlying $D$ aquifer in 1964 averaged about 300 feet higher than that in the $N$ aquifer. Differences in the chemical composition of the waters of the $D$ aquifer and the $N$ aquifer indicate that the amount of downward leakage must be small (Eychaner, 1983). On the average, the concentration of dissolved solids in water from the $D$ aquifer is about 7 times greater than that from the $\mathrm{N}$ aquifer, the concentration of chloride ions is 11 times greater, and the concentration of sulfate ions is 30 times greater (Eychaner, 1983). 
Table 2.--Flowmeter test results for industrial and nonindustrial wells that tap the $N$ aquifer. Black Mesa area, 1988

\begin{tabular}{|c|c|c|c|c|c|c|c|}
\hline $\begin{array}{l}\text { Well } \\
\text { system }\end{array}$ & $\begin{array}{l}\text { Well } \\
\text { number }\end{array}$ & $\begin{array}{l}\text { Date } \\
\text { tested }\end{array}$ & $\begin{array}{l}\text { Test } \\
\text { method }\end{array}$ & $\begin{array}{c}\text { Measured } \\
\text { pumpage } \\
\text { (gal/min) }\end{array}$ & $\begin{array}{c}\text { Metered } \\
\text { pumpage } \\
\text { (gal/min) }\end{array}$ & $\begin{array}{c}\text { Percent } \\
\text { difference }\end{array}$ & $\begin{array}{c}\text { Meter name } \\
\text { and } \\
\text { number }\end{array}$ \\
\hline
\end{tabular}

Navajo Tribal Utility Authority

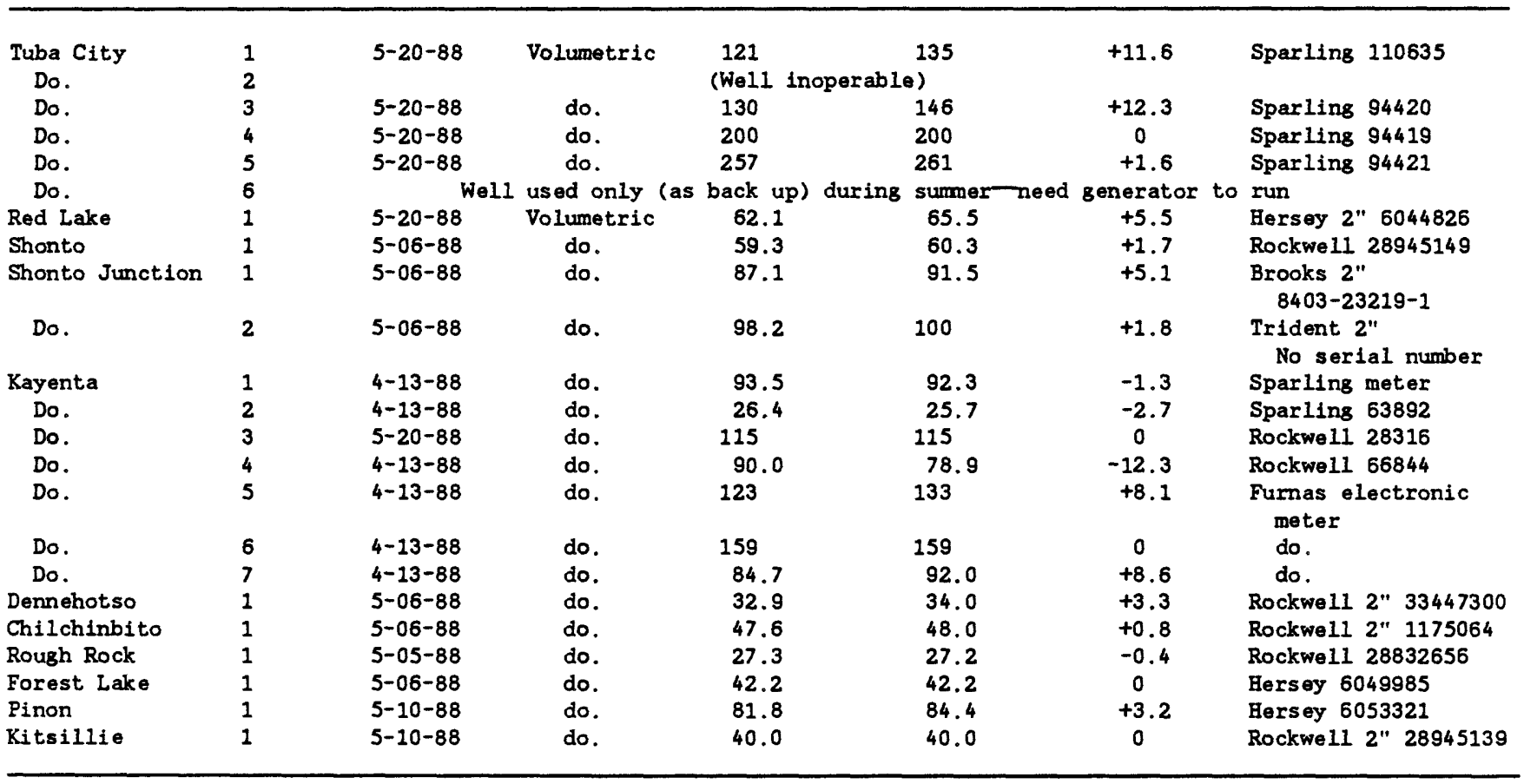

Bureau of Indian Affairs

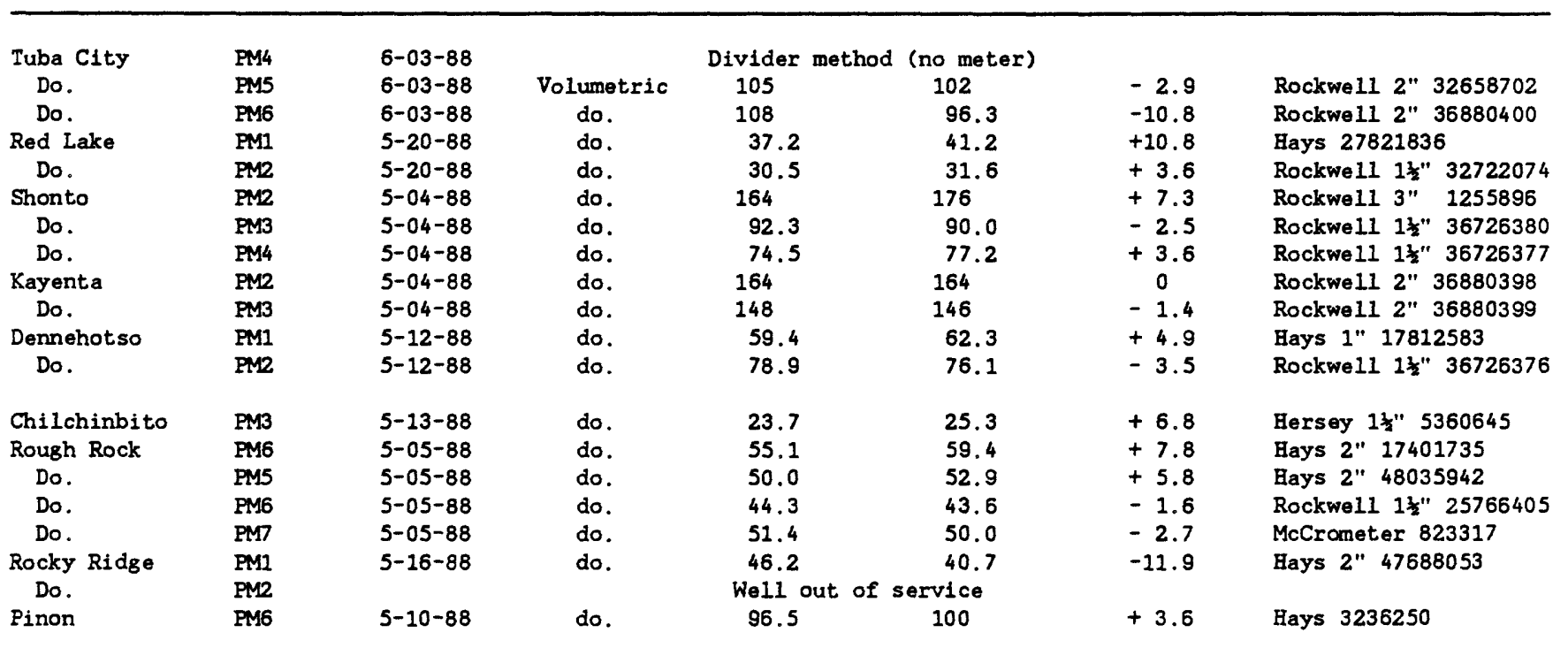

See footnote at end of table. 


\begin{tabular}{|c|c|c|c|c|c|c|c|}
\hline $\begin{array}{l}\text { Well } \\
\text { system }\end{array}$ & $\begin{array}{l}\text { Well } \\
\text { number }\end{array}$ & $\begin{array}{l}\text { Date } \\
\text { tested }\end{array}$ & $\begin{array}{c}\text { Test } \\
\text { method }\end{array}$ & $\begin{array}{c}\text { Measured } \\
\text { pumpage } \\
(\mathrm{gal} / \mathrm{min})\end{array}$ & $\begin{array}{l}\text { Metered } \\
\text { pumpage } \\
\text { (gal/min) }\end{array}$ & $\begin{array}{l}\text { Percent } \\
\text { difference }\end{array}$ & $\begin{array}{c}\text { Meter name } \\
\text { and } \\
\text { number }\end{array}$ \\
\hline
\end{tabular}

Bureau of Indian Affairs--Continued

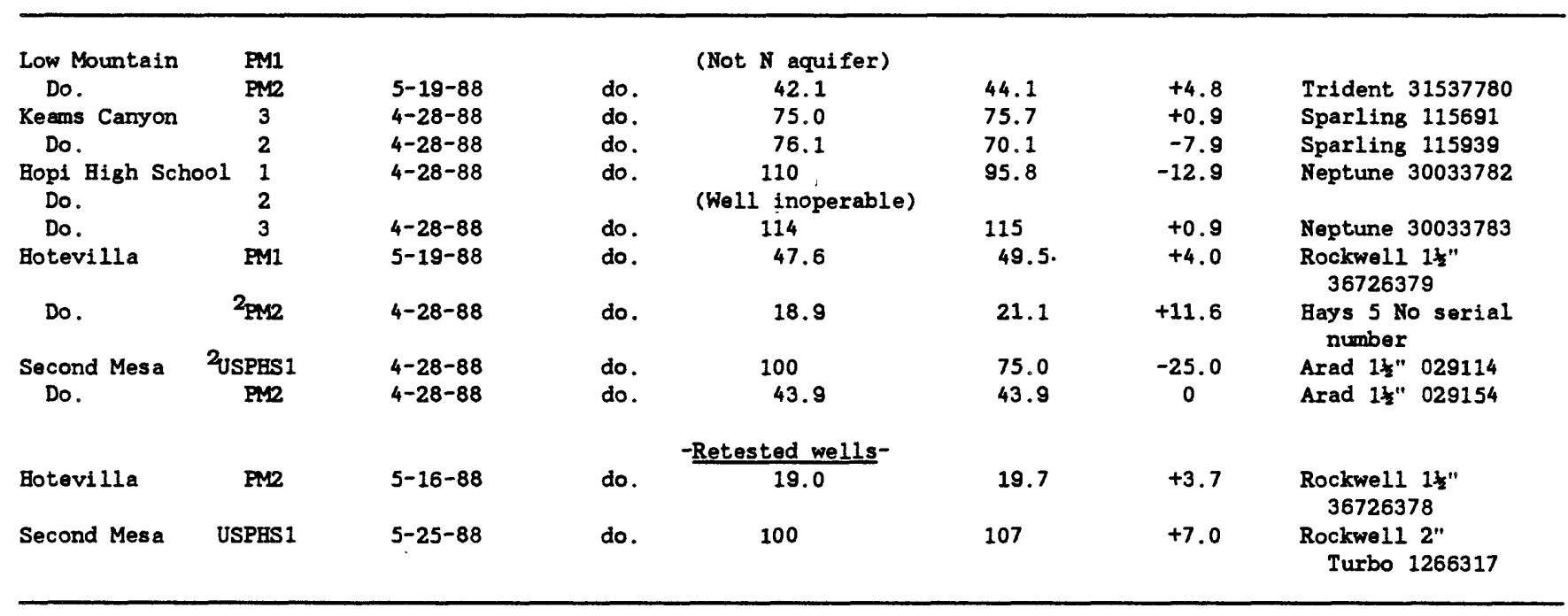

Hopl Tribe

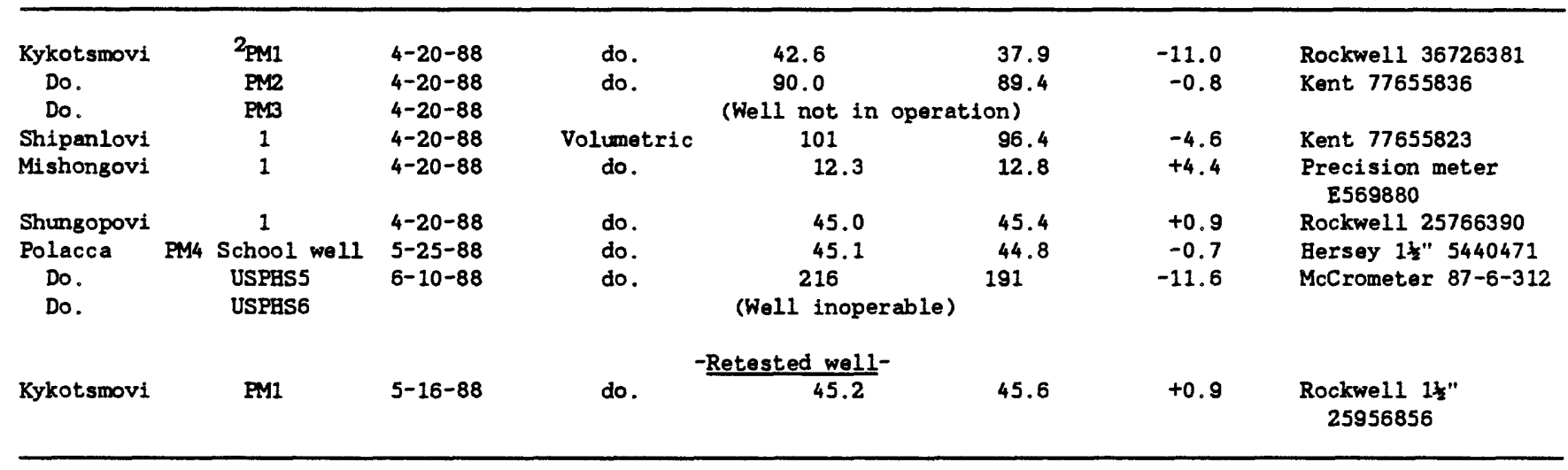

Peabody Coal Co.

\begin{tabular}{|c|c|c|c|c|c|c|c|}
\hline Black Mesa & 2 & $4-12-88$ & $\operatorname{Cox}$ & 476 & 490 & +2.9 & McCrometer $81-6-1088$ \\
\hline Do. & 3 & $4-12-88$ & do. & 583 & 590 & +1.2 & McCrometer 81-6-1087 \\
\hline Do. & 4 & $4-12-88$ & do. & 512 & 530 & +3.5 & S/N 570248 \\
\hline Do. & 5 & $4-12-88$ & do. & 577 & 615 & +6.6 & S/N 776782 \\
\hline Do. & 6 & $4-12-88$ & do. & 472 & 480 & +1.7 & $\begin{array}{l}\text { S/N McCrometer } \\
81-6-108\end{array}$ \\
\hline Do. & 7 & $4-12-88$ & do. & 562 & 560 & -0.4 & S/N 776776 \\
\hline Do. & 8 & $4-12-88$ & do. & 617 & 615 & -0.3 & $\mathrm{~S} / \mathrm{N} 776780$ \\
\hline Do. & 9 & $5-05-88$ & do. & 539 & 565 & +4.8 & $\begin{array}{l}\text { McCrometer } \\
81-6-1082\end{array}$ \\
\hline
\end{tabular}

Twell numbers do not necessarily coincide with Agency well numbers.

2 Well retested after meter change. 
Table 3. - Withdrawals from the $N$ aquifer, $1965-87$

[Measurements are in acre-feet. Data for

1965-79 from Eychaner, 1983]

\begin{tabular}{|c|c|c|c|}
\hline \multirow{2}{*}{ Year } & \multirow{2}{*}{ Industrial ${ }^{1}$} & \multicolumn{2}{|c|}{ Nonindustrial ${ }^{2}, 3$} \\
\hline & & Confined & Unconfined \\
\hline $\begin{array}{l}1965 \\
1966 \\
1967 \\
1968 \\
1969 \\
1970 \\
1971 \\
1972 \\
1973 \\
1974 \\
1975 \\
1976 \\
1977 \\
1978 \\
1979 \\
1980 \\
1981 \\
1982 \\
1983 \\
1984 \\
1985 \\
1986 \\
1987\end{array}$ & $\begin{array}{r}0 \\
0 \\
0 \\
95 \\
43 \\
740 \\
1,900 \\
3,680 \\
3,520 \\
3,830 \\
3,550 \\
4,180 \\
4,090 \\
3,000 \\
3,500 \\
3,540 \\
4,010 \\
4,740 \\
4,460 \\
4,170 \\
2,520 \\
4,480 \\
3,832\end{array}$ & $\begin{array}{r}50 \\
110 \\
120 \\
150 \\
200 \\
280 \\
340 \\
370 \\
530 \\
580 \\
600 \\
690 \\
750 \\
830 \\
860 \\
910 \\
960 \\
870 \\
1,360 \\
1,070 \\
1,040 \\
970 \\
1,134\end{array}$ & $\begin{array}{r}20 \\
30 \\
50 \\
100 \\
100 \\
150 \\
150 \\
250 \\
300 \\
362 \\
508 \\
645 \\
726 \\
930 \\
930 \\
880 \\
1,000 \\
965 \\
1,280 \\
1,400 \\
1,160 \\
1,260 \\
1,277\end{array}$ \\
\hline
\end{tabular}

${ }^{1}$ Metered pumpage by Peabody Coal Company at their mine on Black Mesa.

${ }^{2}$ Does not include withdrawals from the wells equipped with windmills.

${ }^{3}$ Includes estimated pumpage, 1965-73, and metered pumpage, 1974-79, at Tuba City, metered pumpage at Kayenta and estimated pumpage at Chilchinbito, Rough Rock, Pinon, Keams Canyon, and Kykotsmovi prior to 1980; metered and estimated pumpage furnished by the Navajo Tribal Utility Authority and the U.S. Bureau of Indian Affairs and collected by the U.S. Geological Survey, 1980-85; and metered pumpage furnished by the Navajo Tribal Utility Authority, the U.S. Bureau of Indian Affairs, Kykotsmovi Village Administration, and the U.S. Geological Survey, 1986-87. 
[Measurements, in acre-feet, are flowmeter data. BIA, U.S. Bureau of Indian Affairs; NTUA, Navajo Tribal Utility Authority; USGS, U.S. Geological Survey; KVAO, Kykotsmovi Village Administration Office]

\begin{tabular}{|c|c|c|c|c|}
\hline Location & Owner & $\begin{array}{l}\text { Source } \\
\text { of data }\end{array}$ & $\begin{array}{l}\text { Confined aquifer } \\
\text { well systems }\end{array}$ & $\begin{array}{l}\text { Unconfined aquifer } \\
\text { well systems }\end{array}$ \\
\hline Tuba City & BIA & USGS & & 206 \\
\hline Chilchinbito & BIA & USGS & 5.6 & \\
\hline Dennehotso & BIA & BIA & & 23.0 \\
\hline Kayenta & BIA & USGS & 86.0 & \\
\hline Red Lake & BIA & BIA & & 8.8 \\
\hline Rocky Ridge & BIA & USGS & 14.7 & \\
\hline Shonto & BIA & USGS & & 204 \\
\hline Pinon & BIA & BIA & 31.2 & \\
\hline Rough Rock & BIA & BIA & 30.3 & \\
\hline Hotevilla & BIA & USGS & 26.4 & \\
\hline Second Mes a & BIA & USGS & 10.3 & \\
\hline Hopi High School & BIA & USGS & 18.5 & \\
\hline Keams Canyon & BIA & USGS & 75.3 & \\
\hline Low Mountain & BIA & USGS & (1) & \\
\hline Kayenta & NTUA & NTUA & 622 & \\
\hline Chilchinbito & NTUA & NTUA & 30.0 & \\
\hline Dennehotso & NTUA & NTUA & & 31.7 \\
\hline Shonto & NTUA & NTUA & & 22.0 \\
\hline Forrest Lake & NTUA & NTUA & 10.1 & \\
\hline Shonto Junction & NTUA & NTUA & & 16.2 \\
\hline Tuba City & NTUA & NTUA & & 735 \\
\hline Red Lake & NTUA & NTUA & & 30.1 \\
\hline Rough Rock & NTUA & NTUA & 11.2 & \\
\hline Pinon & NTUA & NTUA & 34.3 & \\
\hline Kitsillie & NTUA & NTUA & 7.3 & \\
\hline Mine Well Field & Peabody & Peabody & 3,832 & \\
\hline Polacca & Hopi & USGS & 37.8 & \\
\hline Kykotsmovi & Hop1 & KVAO & 58.3 & \\
\hline Shungopovi & Hopi & USGS & 13.1 & \\
\hline Shipaulovi & Hopi & USGS & 18.5 & \\
\hline Mi shongovi & Hopi & USGS & 1.3 & \\
\hline
\end{tabular}

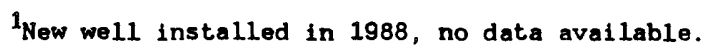

Any increase in the leakage rate as a result of pumping from the $N$ aquifer should appear first as an increase in the dissolved-solids concentrations in the water from Peabody wells (Eychaner, 1983). Other indicators of leakage caused by stress on the $N$ aquifer are increases in specific conductance, concentrations of dissolved chloride, and concentrations of dissolved sulfate.

In 1987-88, all Peabody Coal Company industrial wells (2-9) were sampled for major ions and fluoride. All of these wells penetrate the $\mathrm{N}$ aquifer. On the basis of the analyses of water samples collected from 1967 to 1988 by the Geological Survey, no significant changes have occurred in the quality of water in the mine wells. Chemical analyses of the water from these wells are shown in tables 5 and 6 .

\section{Discharge and Chemical Quality of Springs}

The effect of withdrawals from the $N$ aquifer on the water quality of springs used for domestic purposes is another major concern of some 


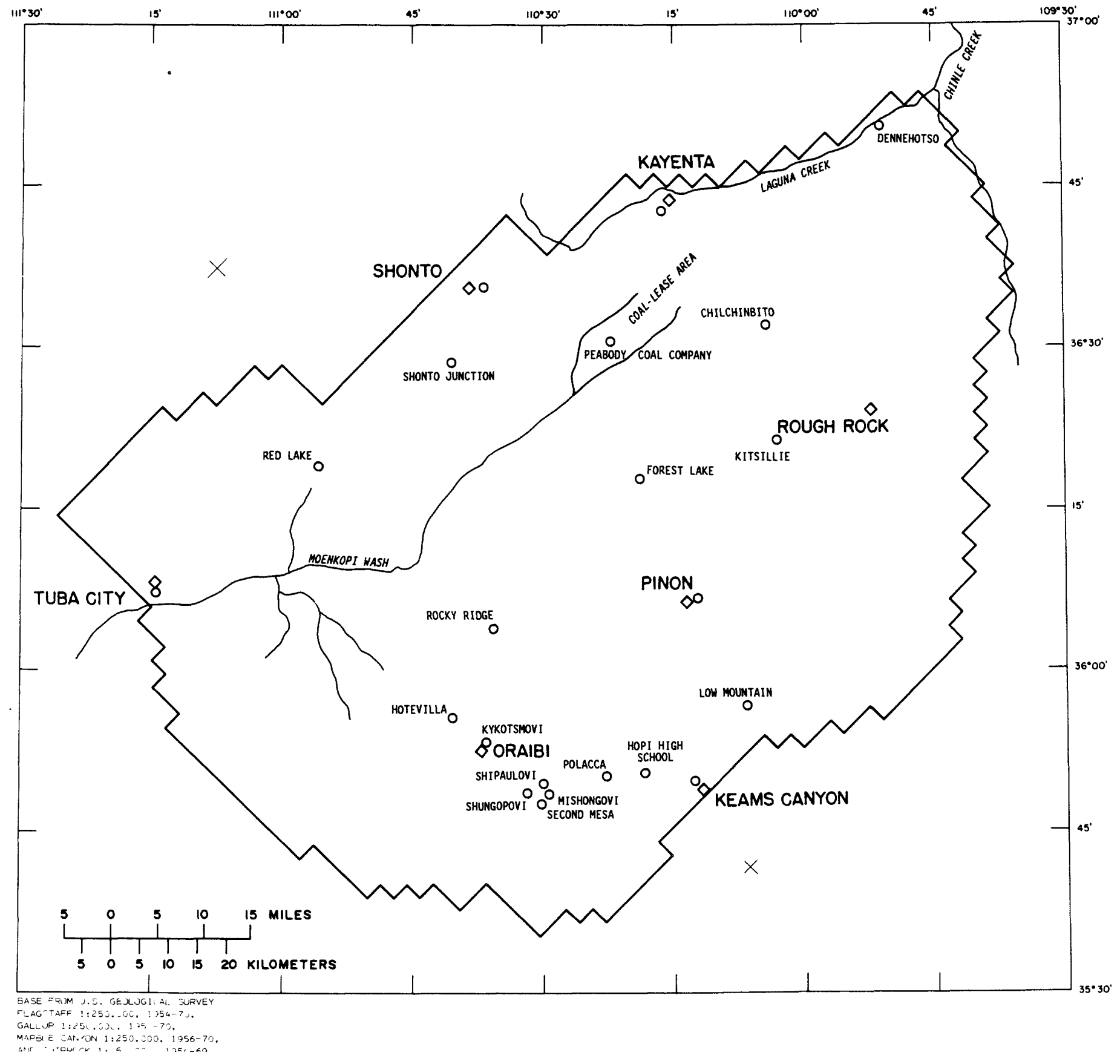

Figure 6.--Location of well systems monitored for withdrawals from the $\mathrm{N}$ aquifer, 1987. 
Table 5.--Chemical analyses of Peabody Coal Company industrial wells that tap the $N$ aouifer. Black Mesa area, 1987-88

\begin{tabular}{|c|c|c|c|c|c|c|c|}
\hline Well number & $\begin{array}{c}\text { Identification } \\
\text { number }\end{array}$ & $\begin{array}{l}\text { Date of } \\
\text { sample }\end{array}$ & $\begin{array}{c}\text { Temper- } \\
\text { ature } \\
\left({ }^{\circ} \mathrm{C}\right)\end{array}$ & $\begin{array}{c}\text { Spe- } \\
\text { cific } \\
\text { conduct- } \\
\text { ance } \\
(\mu \mathrm{S} / \mathrm{cm})\end{array}$ & $\underset{\text { (units) }}{\mathrm{pH}}$ & $\begin{array}{c}\text { Alka- } \\
\text { linity } \\
(\mathrm{mg} / \mathrm{L} \text { as } \\
\left.\mathrm{CaCO}_{3}\right)\end{array}$ & $\begin{array}{c}\text { Nitrogen, } \\
\mathrm{NO}_{2}+\mathrm{NO}_{3} \\
\text { dissolved } \\
\text { (mg/L as } \mathrm{N} \text { ) }\end{array}$ \\
\hline
\end{tabular}

\begin{tabular}{|c|c|c|c|c|c|c|c|c|}
\hline Peabody & Well 2 & 363005110250901 & $12-02-87$ & 32 & 149 & 8.8 & 99 & 0.94 \\
\hline Peabody & Wel1 3 & 362625110223701 & $12-02-87$ & 32.5 & 171 & 9.2 & 81 & .80 \\
\hline Peabody & Well 4 & 362647110243501 & $12-02-87$ & 32 & 194 & 9.2 & 97 & .97 \\
\hline Peabody & Well 5 & 362901110234101 & $01-05-88$ & 32 & 270 & 9.4 & 116 & .86 \\
\hline Peabody & Well 6 & 363007110221201 & $01-05-88$ & 34 & 173 & 9.1 & 89 & .64 \\
\hline Peabody & We11 7 & 362456110242301 & $01-05-88$ & 32 & 240 & 9.5 & 96 & .74 \\
\hline Peabody & Wel1 8 & 363130110254501 & $01-05-88$ & 29.5 & 790 & 8.2 & 135 & 2.1 \\
\hline Do. & & do. & $03-03-88$ & 29.5 & 438 & 7.8 & 100 & 1.3 \\
\hline Peabody & Wel1 9 & 362333112500001 & $12-02-87$ & 32 & 148 & 9.0 & 73 & .72 \\
\hline
\end{tabular}

\begin{tabular}{|c|c|c|c|c|c|c|}
\hline We11 number & Identification & Date of & $\begin{array}{l}\text { Phos- } \\
\text { phorus, } \\
\text { ortho, }\end{array}$ & $\begin{array}{l}\text { Calcium, } \\
\text { dissolved }\end{array}$ & $\begin{array}{l}\text { Magnesium, } \\
\text { dissolved }\end{array}$ & $\begin{array}{l}\text { Sodium, } \\
\text { dissolved }\end{array}$ \\
\hline & & & $\begin{array}{l}\text { dissolved } \\
(m g / L \text { as } \text { P) }\end{array}$ & (mg/L as Ca) & $(\mathrm{mg} / \mathrm{L}$ as $\mathrm{Mg})$ & $(\mathrm{mg} / \mathrm{L}$ as $\mathrm{Na})$ \\
\hline
\end{tabular}

Peabody Well 2 Peabody Well 3 Peabody Well 4 Peabody Well 5 Peabody Well 6 Peabody Well 7 Peabody Well 8 Do.

Peabody Well 9
363005110250901 362625110223701 362647110243501 362901110234101 363007110221201 362456110242301 363130110254501 do.

362333112500001

$12-02-87$
$12-02-87$
$12-02-87$
$01-05-88$
$01-05-88$
$01-05-88$
$01-05-88$
$03-03-88$
$12-02-87$

$<0.01$

$<.01$

$<.01$

.01

$<.01$

$<.01$

$<.01$

.07

.09

\section{9}

3.9

4.8

3.3

4.3

3.9

31

22

3.6

0.17
$<.01$
$<.01$
.04
.05
.10
6.2
3.3
.03

26

35

41

61

38

71

31

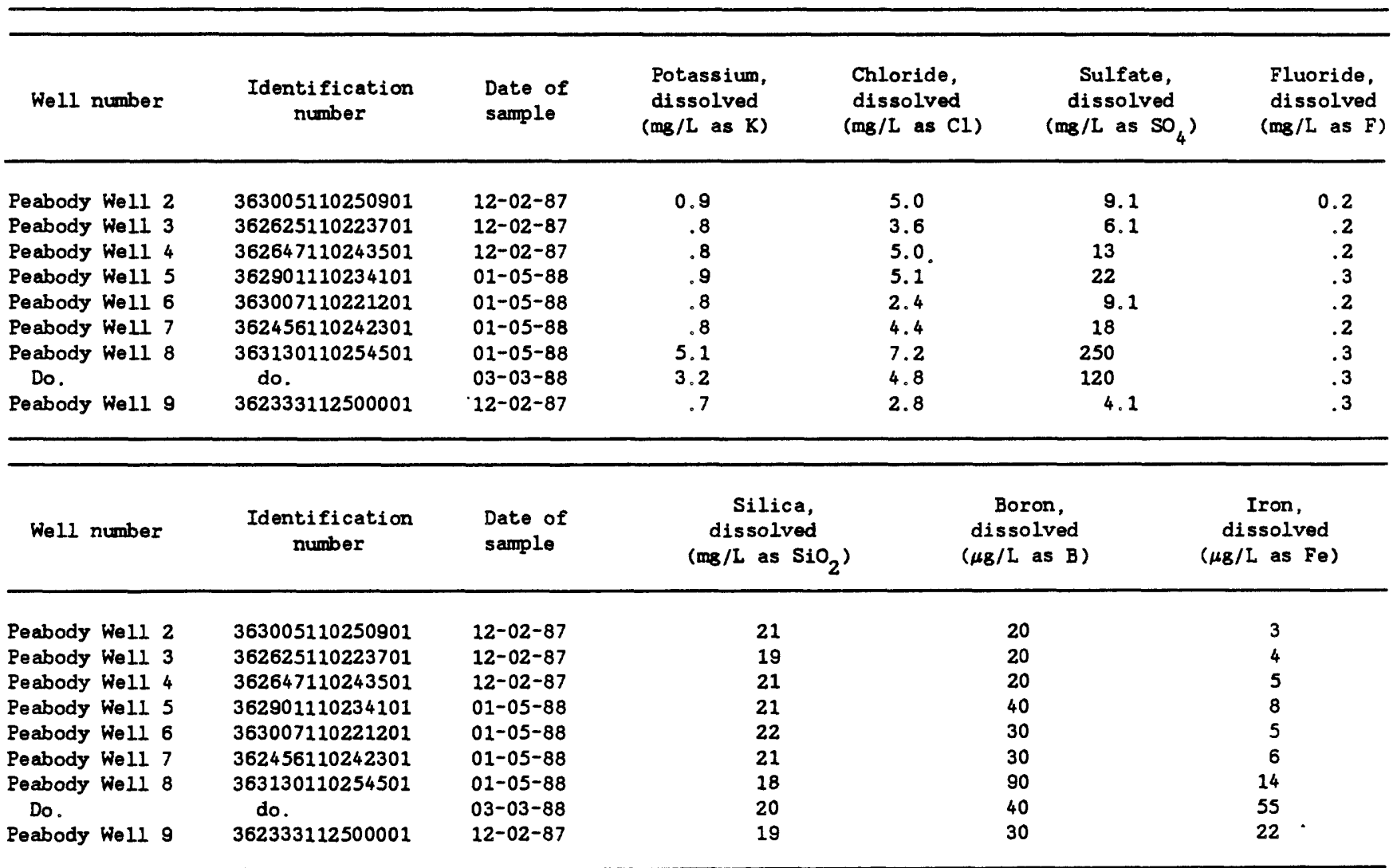


Table 6. --Selected parameters from chemical analyses of water from

Peabody Coal Company wells that tap the $N$ aquifer, Black Mesa

area, $1967-74$ and $1980-88$

\begin{tabular}{|c|c|c|c|c|c|}
\hline $\begin{array}{l}\text { Well } \\
\text { number }\end{array}$ & Year & $\begin{array}{c}\text { Specific } \\
\text { conductance } \\
(\mu \mathrm{S} / \mathrm{cm})\end{array}$ & $\begin{array}{c}\text { Dissolved-solids } \\
\text { concentrations, } \\
\text { residue at } 180^{\circ} \mathrm{C} \\
(\mathrm{mg} / \mathrm{L})\end{array}$ & $\begin{array}{l}\text { Chloride, } \\
\text { dissolved } \\
\text { (ms/L as } \mathrm{Cl} \text { ) }\end{array}$ & $\begin{array}{c}\text { Sulfate, } \\
\text { dissolved } \\
\left(\mathrm{mg} / \mathrm{L} \text { as } \mathrm{SO}_{4}\right)\end{array}$ \\
\hline \multirow[t]{4}{*}{2} & 1967 & 221 & $1_{144}$ & 5.0 & 21 \\
\hline & 1980 & 225 & 144 & 11 & 20 \\
\hline & 1986 & 172 & -- & 2.6 & 8.1 \\
\hline & 1987 & 149 & 113 & 5.0 & 9.1 \\
\hline \multirow[t]{4}{*}{3} & 1968 & 236 & $1_{154}$ & 4.0 & 17 \\
\hline & 1980 & 230 & 151 & 3.5 & 14 \\
\hline & 1986 & 175 & - & 2.4 & 9.7 \\
\hline & 1987 & 171 & 111 & 3.6 & 6.1 \\
\hline \multirow[t]{4}{*}{4} & 1974 & 200 & 140 & 3.8 & 13 \\
\hline & 1980 & 230 & 139 & 4.3 & 13 \\
\hline & 1986 & 205 & -- & 4.2 & 12 \\
\hline & 1987 & 194 & 135 & 5.0 & 13 \\
\hline \multirow[t]{6}{*}{5} & 1968 & 224 & $1_{149}$ & 3.5 & 16 \\
\hline & 1980 & 210 & 134 & 2.9 & 9.5 \\
\hline & 1986 & 398 & -- & 8.0 & 28 \\
\hline & $2_{1986}$ & 602 & 338 & 12.0 & 62 \\
\hline & 1987 & 270 & 168 & 4.6 & 21 \\
\hline & 1988 & 270 & 184 & 5.1 & 22 \\
\hline \multirow[t]{4}{*}{6} & 1968 & 201 & $1_{333}$ & 3.0 & 13 \\
\hline & 1980 & 260 & 160 & 3.5 & 15 \\
\hline & 1986 & 182 & -- & 2.3 & 9.6 \\
\hline & 1988 & 173 & 127 & 2.4 & 9.1 \\
\hline \multirow[t]{4}{*}{7} & 1972 & 222 & $1_{141}$ & 2.5 & 20 \\
\hline & 1980 & 210 & 136 & 3.7 & 11 \\
\hline & 1986 & 217 & -- & 3.6 & 12 \\
\hline & 1988 & 240 & 151 & 4.4 & 18 \\
\hline \multirow[t]{6}{*}{8} & 1980 & 420 & 283 & 4.8 & 100 \\
\hline & 1983 & 440 & 278 & 4.8 & 100 \\
\hline & 1984 & 436 & 264 & 4.7 & 100 \\
\hline & 1986 & 445 & -- & 4.9 & 110 \\
\hline & 3988 & 790 & 516 & 7.2 & 250 \\
\hline & $4_{1988}$ & 438 & 300 & 4.8 & 120 \\
\hline \multirow[t]{2}{*}{9} & 1986 & 181 & $\ldots$ & 3.1 & 4.9 \\
\hline & 1987 & 148 & 102 & 2.8 & 4.1 \\
\hline
\end{tabular}

${ }^{1}$ Dissolved-solids concentrations from 1974.

${ }^{2}$ volume of well bore not completely displaced prior to sampling.

3 Well pumped for 16 hours at 470 gallons per minute.

4 well pumped for 20 hours at 600 gallons per minute. 
residents of the reservations. Many springs on Black Mesa discharge from several stratigraphic units including the Navajo Sandstone where these units crop out.

Four springs were selected for discharge measurements and waterquality analyses during 1987. The springs were Shonto Spring (6M-54, Navajo Sandstone), Spring near Dennehotso (8A-224, Navajo Sandstone), Hard Rocks Spring (4M-128, Wepo Formation), and Tuye Spring (or spring near Steamboat, 17M-261, Dakota Sandstone). Shonto Spring was previously sampled in 1952 and 1984, Spring near Dennehotso in 1984, Hard Rocks Spring in 1952 and 1982, and Tuye Spring in 1949 and 1984. Discharge measurements for these springs are as follows:

\begin{tabular}{|c|c|c|c|}
\hline Spring & $\begin{array}{c}\text { Bureau of } \\
\text { Indian Affairs } \\
\text { Number } \\
\end{array}$ & Year & $\begin{array}{l}\text { Discharge, in } \\
\text { gallons per minute }\end{array}$ \\
\hline Shonto & $6 M-54$ & $\begin{array}{l}1952 \\
1984 \\
1987\end{array}$ & $\begin{array}{c}1 \text { (estimated) } \\
0.67 \\
\text { Collection wel1 } \\
\text { (unmeasurable) }\end{array}$ \\
\hline Dennehotso & $8 A-224$ & $\begin{array}{l}1984 \\
1987\end{array}$ & $\begin{array}{l}2 \\
5\end{array}$ \\
\hline Hard Rocks & $4 M-128$ & $\begin{array}{l}1952 \\
1982 \\
1987\end{array}$ & $\begin{array}{l}1 \text { (estimated) } \\
\text { Not measured } \\
2\end{array}$ \\
\hline Tuye & $17 M-261$ & $\begin{array}{l}1949 \\
1984 \\
1987\end{array}$ & $\begin{array}{c}\text { Collection well } \\
\text { (unmeasurable) } \\
\text { do. } \\
\text { do. }\end{array}$ \\
\hline
\end{tabular}

On the basis of the analyses of water samples collected from the early 1950 's to 1987 by the U.S. Geological Survey, no significant changes have occurred in the quality of water in these springs. Chemical analyses for the springs for all years sampled are shown in table 7. Discharges and chemical analyses of other springs have been reported previously (G.W. Hill, written commun., 1982, 1983; Hil1, 1985; Hill and whetten, 1986; Hil1 and Sottilare, 1987).

\section{Surface-Water Data}

Outflow from the $N$ aquifer appears mainly as surface flow in Moenkopi Wash and Laguna Creek and as springs near the boundaries of the aquifer (Davis and others, 1963). Data were collected from the continuousrecord streamflow stations on Moenkopi Wash at Moenkopi (09401260) and Chinle Creek near Mexican Water (09379200) and from the low-flow measurement site on Laguna Creek near Church Rock (fig. 3).

The average discharge of low-flow measurements made on Moenkopi Wash during November through February in the 1988 water year was 3.6 cubic 


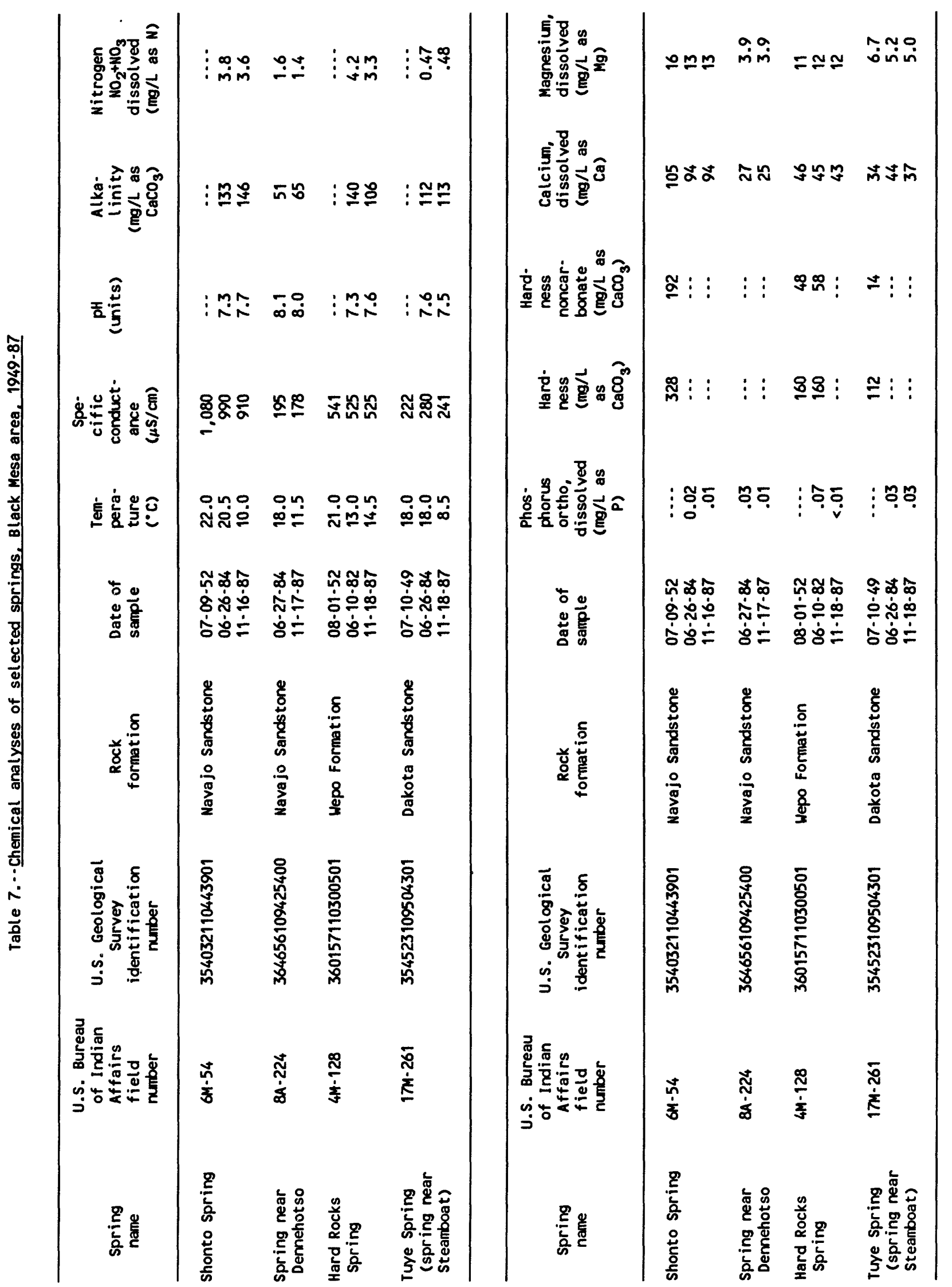




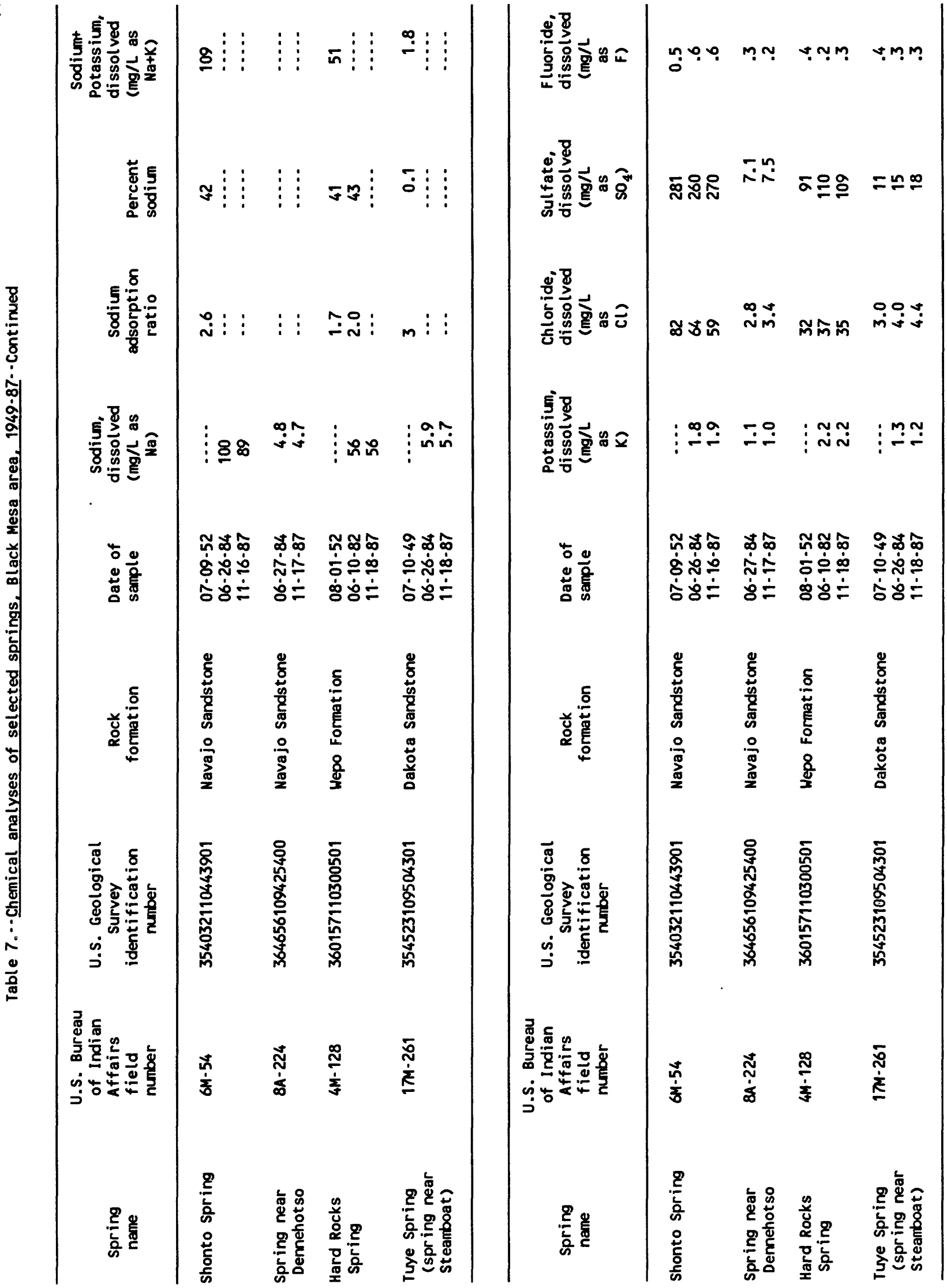




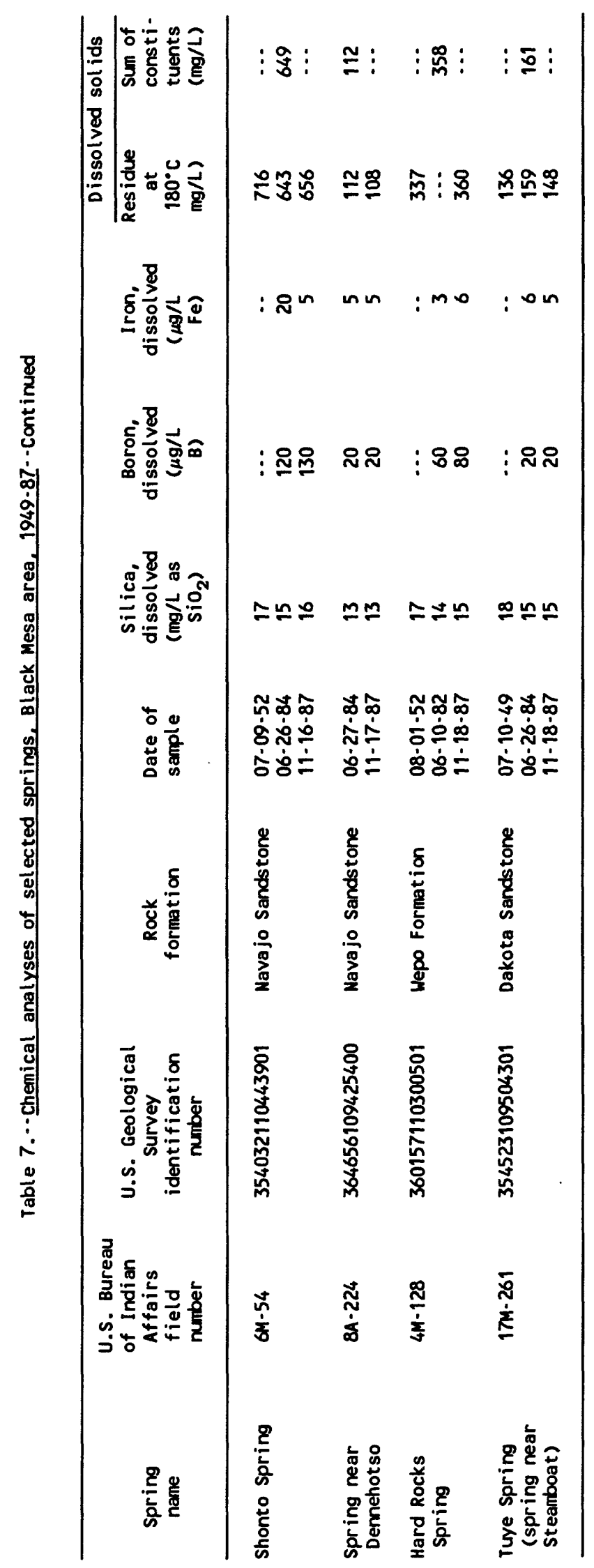


feet per second, which is equivalent to about 2,602 acre-feet per year. The average of all measurements made during the same period from 1976 to 1988 was 3.2 cubic feet per second. Low flow in Moenkopi Wash during November through February has remained fairly constant since the streamflow station was established in 1976. Mean daily discharges during the 1986 water year are shown in table 8. Mean daily discharges for previous water years have been published in Water Resources Data for Arizona (U.S. Geological Survey, 1977-88).

Chinle Creek, which is along the northeast perimeter of the study area, receives water from the $\mathrm{N}$ aquifer principally from Laguna Creek. Laguna Creek flows along the north boundary of the study area and flows into the Chinle Creek about 5 miles above the gaging station near Mexican Water (fig. 3). The average discharge of low-flow measurements made on Chinle Creek for November through February in the 1987 water year was 3.6 cubic feet per second or about 2,602 acre-feet per year. The average discharge of low-flow measurements for the same months during water years 1977-88 was 7.4 cubic feet per second or about 5,348 acre-feet per year. The mean daily discharges for the 1986 water year are shown on table 9 . All previous mean daily discharges have been published in Water Resources Data for Arizona (U.S. Geological Survey, 1964-88).

The average discharge of low-flow measurements made on Laguna Creek during November through February since the station was established in 1981 is 3.4 cubic feet per second or about 2,460 acre-feet per year. Only one low-flow measurement was made during the same months in the 1988 water year; the discharge for that measurement was 1.89 cubic feet per second. Continuous streamflow data are not collected at this station.

\section{REFERENCES CITED}

Brown, J.G., and Eychaner, J.H., 1988, Simulation of five ground-water withdrawal projections for the Black Mesa area, Navajo and Hopi Indian Reservations, Arizona: U.S. Geological Survey WaterResources Investigations Report 88-4000, $51 \mathrm{p}$.

Davis, G.E., Hardt, W.F., Thompson, L.K., and Cooley, M.E., 1963, Records of ground-water supplies, part 1 of Geohydrologic data in the Navajo and Hopi Indian Reservations, Arizona, New Mexico, and Utah: Arizona State Land Department Water-Resources Report 12-A, $159 \mathrm{p}$.

Eychaner, J.H., 1983, Geohydrology and effects of water use in the Black Mesa area, Navajo and Hopi Indian Reservations, Arizona: U.S . Geological Survey Water-Supply Paper 2201, 26 p.

Hill, G.W., 1985, Progress report on Black Mesa monitoring program-1984: U.S. Geological Survey Open-File Report 85-483, 24 p.

Hill, G.W., and Sottilare, J.P., 1987, Progress report on the ground-water, surface-water, and quality-of-water monitoring program, Black Mesa area, northeastern Arizona-1987: U.S. Geological Survey Open-File Report $87-458,29$ p. 
Hill, G.W., and Whetten, M.I., 1986, Progress report on Black Mesa monitoring program-1985-86: U.S. Geological Survey Open-File Report 86-414, 23 p.

U.S. Geological Survey, 1978, Progress report on Black Mesa monitoring program-1977: U.S. Geological Survey Open-File Report 78-459, $38 \mathrm{p}$.

1964-88, Water resources data for Arizona, water years 1963-85: U.S. Geological Survey Water-Data reports (published annually). 
Table 8. --Discharge data, Moenkopi Wash at Moenkopi, 1986 water year

DISCHARGE, IN CUBIC FEET PER SECOND, WATER YEAR OCTOBER 1985 TO SEPTEMBER 1986 MEAN VALUES

\begin{tabular}{|c|c|c|c|c|c|c|c|c|c|c|c|c|}
\hline DAY & $\infty I$ & NOV & DEC & JAN & FEB & MAR & APR & MAY & JUN & JUL & AUG & SEP \\
\hline 1 & 1.2 & 13 & 16 & 5.6 & 3.0 & 2.8 & 3.6 & 3.6 & .36 & .00 & .00 & 1.6 \\
\hline 2 & 1.2 & 2.2 & 10 & 5.6 & 3.0 & 2.8 & 3.6 & 2.5 & .20 & .00 & .00 & .17 \\
\hline 3 & 1.0 & 2.2 & 5.6 & 5.6 & 3.0 & 2.8 & 3.6 & 2.5 & .17 & .00 & .00 & .15 \\
\hline 4 & .36 & 2.2 & 3.6 & 5.6 & 3.0 & 2.8 & 3.6 & 2.8 & .20 & .00 & .00 & .10 \\
\hline 5 & .20 & 2.2 & 4.4 & 16 & 3.0 & 2.8 & 3.6 & 2.5 & .20 & .08 & .00 & .00 \\
\hline 6 & .12 & 1.6 & 4.4 & 3.6 & 3.0 & 2.8 & 3.6 & 2.5 & .17 & 2.2 & .00 & .00 \\
\hline 7 & .12 & 1.6 & 3.6 & 3.0 & 3.0 & 2.8 & 3.6 & 2.0 & .02 & .02 & .00 & .00 \\
\hline 8 & .12 & 2.2 & 3.6 & 3.0 & 3.0 & 2.8 & 3.6 & 2.0 & .00 & .00 & .00 & .00 \\
\hline 9 & .12 & 2.8 & 3.6 & 3.0 & 3.0 & 2.8 & 3.0 & 1.8 & .00 & .00 & .00 & 1,070 \\
\hline 10 & 3.6 & 2.8 & 3.6 & 3.0 & 2.0 & 2.2 & 2.8 & 1.6 & .00 & .00 & .00 & 238 \\
\hline 11 & 2.8 & 2.8 & 3.6 & 3.0 & 2.5 & 2.2 & 2.8 & 1.6 & .00 & .00 & .36 & 38 \\
\hline 12 & 2.2 & 2.8 & 3.6 & 3.0 & 3.0 & 2.2 & 2.8 & 1.6 & .00 & .00 & 1.0 & 16 \\
\hline 13 & 1.6 & 2.8 & 3.6 & 3.0 & 3.0 & 2.2 & 2.8 & 1.2 & .00 & .00 & .20 & 8.4 \\
\hline 14 & 1.6 & 2.8 & 3.6 & 3.0 & 3.0 & 2.2 & 2.8 & 1.0 & .00 & .00 & 6.8 & 2.2 \\
\hline 15 & 1.6 & 2.8 & 4.4 & 3.0 & 3.0 & 2.2 & 2.5 & 1.0 & .00 & .00 & 6.8 & 1.0 \\
\hline 16 & 1.6 & 2.8 & 10 & 3.0 & 3.5 & 2.2 & 2.5 & 1.0 & .00 & 23 & .36 & 1.0 \\
\hline 17 & 1.6 & 4.4 & 3.6 & 3.0 & 4.0 & 2.2 & 2.5 & 1.2 & .00 & 24 & .00 & .80 \\
\hline 18 & 1.6 & 8.4 & 3.6 & 3.0 & 4.0 & 2.2 & 2.5 & 1.2 & .00 & 4.4 & .00 & .80 \\
\hline 19 & 1.6 & 5.6 & 3.6 & 3.0 & 4.5 & 1.6 & 2.5 & 1.0 & .00 & .27 & .00 & .80 \\
\hline 20 & 1.6 & 3.6 & 3.6 & 3.0 & 4.4 & 1.6 & 2.5 & 1.0 & .00 & 83 & .00 & .47 \\
\hline 21 & 1.6 & 3.6 & 3.6 & 3.0 & 4.0 & 1.6 & 2.5 & .80 & .00 & 155 & .00 & .47 \\
\hline 22 & 1.6 & 2.2 & 3.6 & 2.8 & 3.5 & 1.6 & 2.5 & .80 & .00 & 134 & .00 & .47 \\
\hline 23 & 1.6 & 2.2 & 3.6 & 3.0 & 3.0 & 1.6 & 2.2 & .80 & .00 & 34 & .00 & 16 \\
\hline 24 & 1.6 & 2.2 & 3.6 & 3.0 & 3.0 & 1.6 & 2.0 & .80 & .00 & 47 & 11 & 499 \\
\hline 25 & 1.6 & 4.4 & 3.6 & 3.0 & 3.0 & 1.6 & 2.0 & .80 & .00 & 47 & 240 & 88 \\
\hline 26 & 1.6 & 36 & 3.6 & 3.0 & 2.8 & 1.6 & 2.0 & .80 & .00 & 4.4 & 127 & 16 \\
\hline 27 & 1.6 & 8.0 & 3.6 & 3.0 & 2.8 & 1.6 & 2.0 & .60 & .00 & 2.2 & 10 & 8.4 \\
\hline 28 & 1.6 & 2.8 & 3.6 & 3.0 & 2.8 & 10 & 2.0 & .60 & .00 & .47 & 112 & 2.8 \\
\hline 29 & 1.6 & 2.8 & 3.6 & 3.0 & -- & 3.6 & 2.0 & .60 & .00 & .17 & 100 & 2.8 \\
\hline 30 & 1.6 & 182 & 3.6 & 3.0 & -- & 3.6 & 2.0 & .60 & .00 & .00 & 170 & 2.2 \\
\hline 31 & 1.6 & --- & 4.4 & 3.0 & --- & 3.6 & -- & .47 & -- & .00 & 8.4 & $\cdots$ \\
\hline TOTAL & 43.44 & 317.8 & 142.0 & 116.8 & 88.8 & 80.2 & 82.0 & 43.27 & 1.32 & 561.21 & 793.92 & $2,015.63$ \\
\hline MEAN & 1.40 & 10.6 & 4.58 & 3.77 & 3.17 & 2.59 & 2.73 & 1.40 & .044 & 18.1 & 25.6 & 67.2 \\
\hline MAX & 3.6 & 182 & 16 & 16 & 4.5 & 10 & 3.6 & 3.6 & .36 & 155 & 240 & 1,070 \\
\hline MIN & .12 & 1.6 & 3.6 & 2.8 & 2.0 & 1.6 & 2.0 & .47 & .00 & .00 & .00 & .00 \\
\hline$A C-F T$ & 86 & 630 & 282 & 232 & 176 & 159 & 163 & 86 & 2.6 & 1,110 & 1,570 & 4,000 \\
\hline
\end{tabular}

CAL YR 1985 TOTAL 1563.83 MEAN 4.26 MAX 182 MIN .00 AC-FT 3,100

WTR YR 1986 TOTAL 4286.38 MEAN 11.7 MAX 1,070 MIN .00 AC-FT 8,500 
Table 9.--Discharge data. Chinle Creek near Mexican Water, 1986 water year

DISCHARGE, IN CUBIC FEET PER SECOND, WATER YEAR OCTOBER 1985 TO SEPTEMBER 1986 MEAN VALUES

\begin{tabular}{|c|c|c|c|c|c|c|c|c|c|c|c|c|}
\hline DAY & $\infty \mathrm{T}$ & Nov & DEC & JAN & FEB & MAR & APR & MAY & $\pi N$ & JUL & AUG & SEP \\
\hline 1 & .5 & 5.7 & 171 & 14 & 3.4 & 2.0 & 19 & 6.5 & .20 & .00 & .00 & 157 \\
\hline 2 & .5 & 5.7 & 110 & 20 & .20 & 1.4 & 15 & 9.6 & .10 & .00 & .00 & 176 \\
\hline 3 & .4 & 6.2 & 52 & 11 & .30 & 1.4 & 41 & 14 & .00 & .00 & .00 & 133 \\
\hline 4 & .4 & 6.2 & 36 & 13 & .20 & 1.5 & 171 & 12 & .00 & .00 & .00 & 110 \\
\hline 5 & .4 & 5.3 & 24 & 8.4 & .00 & 1.2 & 123 & 8.0 & .00 & 46 & .00 & 17 \\
\hline 6 & .3 & 5.7 & 21 & 8.4 & 1.0 & 1.4 & 119 & 6.0 & .00 & 17 & .00 & 21 \\
\hline 7 & .10 & 6.2 & 19 & 11 & 1.0 & 1.2 & 106 & 4.0 & .00 & 1.8 & .00 & 44 \\
\hline 8 & 5.0 & 6.2 & 18 & 15 & 1.0 & 1.5 & 73 & 2.0 & .00 & .40 & .00 & 147 \\
\hline 9 & 5.0 & 5.7 & 18 & 13 & 1.0 & 1.2 & 50 & 1.0 & .00 & .90 & .00 & 580 \\
\hline 10 & 20 & 5.7 & 10 & 15 & 1.0 & 1.4 & 40 & .50 & .00 & .40 & .00 & 771 \\
\hline 11 & 600 & 4.8 & 7.2 & 18 & 1.0 & 2.0 & 21 & .50 & .00 & .00 & .00 & 189 \\
\hline 12 & 200 & 6.5 & 4.1 & 19 & 1.0 & 2.0 & 18 & .50 & .00 & .00 & .00 & 62 \\
\hline 13 & 100 & 6.2 & 4.8 & 15 & 3.0 & 4.1 & 5.3 & .30 & .00 & .00 & 147 & 21 \\
\hline 14 & 60 & 11 & 3.4 & 10 & 5.0 & 4.8 & 2.0 & .30 & .00 & .00 & 74 & 15 \\
\hline 15 & 20 & 17 & 2.8 & 10 & 5.0 & 6.5 & 1.1 & .20 & .00 & .00 & 20 & 8.4 \\
\hline 16 & 10 & 6.5 & 1.8 & 10 & 5.0 & 5.7 & 1.5 & 2.2 & .00 & 19 & 7.2 & 5.7 \\
\hline 17 & 5.0 & 7.6 & 1.4 & 10 & 5.0 & 8.8 & 1.5 & 14 & .00 & 9.6 & .40 & 1.0 \\
\hline 18 & 4.0 & 9.2 & 2.5 & 10 & 5.0 & 7.2 & 1.5 & 2.2 & .00 & .50 & .20 & 1.0 \\
\hline 19 & 4.0 & 12 & 4.4 & 10 & 5.0 & 6.9 & 2.0 & 1.4 & .00 & 10 & .10 & 1.0 \\
\hline 20 & 4.0 & 6.9 & 3.4 & 10 & 5.0 & 9.2 & 2.0 & .60 & .00 & 142 & .00 & 1.0 \\
\hline 21 & 4.0 & 4.4 & 3.7 & 10 & 3.1 & 5.3 & 2.0 & .40 & .00 & 30 & 10 & .90 \\
\hline 22 & 4.0 & 3.7 & 1.5 & 10 & 2.0 & 3.7 & 2.5 & .20 & .00 & 191 & 8.0 & .90 \\
\hline 23 & 4.0 & 4.8 & 3.7 & 5.3 & 4.4 & 2.0 & 3.0 & .30 & .00 & 160 & .90 & 1.8 \\
\hline 24 & 4.0 & 11 & 5.7 & 12 & 2.0 & .90 & 8.0 & .40 & .00 & 488 & 19 & 150 \\
\hline 25 & 3.7 & 15 & 12 & 13 & 2.5 & .80 & 8.0 & .30 & .00 & 124 & 436 & 768 \\
\hline 26 & 3.7 & 14 & 14 & 11 & 1.2 & .50 & 4.8 & .30 & .00 & 12 & 25 & 110 \\
\hline 27 & 3.7 & 74 & 12 & 12 & 2.0 & 2.5 & 17 & .20 & .00 & .10 & 7.2 & 82 \\
\hline 28 & 3.7 & 52 & 9.6 & 17 & 2.2 & 1.2 & 20 & .20 & .00 & .00 & 62 & 39 \\
\hline 29 & 4.1 & 38 & 5.0 & 9.2 & -- & 1.0 & 8.0 & .20 & .00 & .00 & 134 & 15 \\
\hline 30 & 4.1 & 127 & 3.0 & 8.4 & $\ldots$ & .30 & 4.8 & .10 & .00 & .00 & 255 & 12 \\
\hline 31 & 4.8 & -- & 15 & 14 & --- & .30 & --- & .20 & -- & .00 & 74 & - \\
\hline TOTAL & 1083.40 & 490.2 & 600.0 & 372.7 & 68.50 & 89.90 & 891.0 & 88.60 & .30 & $1,252.70$ & $1,280.00$ & $3,640.70$ \\
\hline MEAN & 34.9 & 16.3 & 19.4 & 12.0 & 2.45 & 2.90 & 29.7 & 2.86 & .010 & 40.4 & 41.3 & 121 \\
\hline MAX & 600 & 127 & 171 & 20 & 5.0 & 9.2 & 171 & 14 & .20 & 488 & 436 & 771 \\
\hline MIN & .10 & 3.7 & 1.4 & 5.3 & .00 & .30 & 1.1 & .10 & .00 & .00 & .00 & .90 \\
\hline$A C-F T$ & 2150 & 972 & 1190 & 739 & 136 & 178 & 1,770 & 176 & .6 & 2,480 & 2,540 & 7220 \\
\hline
\end{tabular}

CAL YR 1985 TOTAL 25713.59 MEAN 70.4 MAX 2,280 MIN .00 AC-FT 5, 100

WTR YR 1985 TOTAL 9857.97 MEAN 27.0 MAX 771 MIN .00 AC-FT 19,550 